\title{
Seasonal budgets of reactive nitrogen species and ozone over the United States, and export fluxes to the global atmosphere
}

\author{
Jinyou Liang, ${ }^{1}$ Larry W. Horowitz, ${ }^{2}$ Daniel J. Jacob, Yuhang Wang, ${ }^{3}$ Arlene M. Fiore, \\ Jennifer A. Logan, Geraldine M. Gardner, and J. William Munger \\ Department of Earth and Planetary Sciences and Division of Engineering and Applied Sciences Harvard University \\ Cambridge, MA
}

\begin{abstract}
A three-dimensional, continental-scale photochemical model is used to investigate seasonal budgets of $\mathrm{O}_{3}$ and $\mathrm{NO}_{3}$ species (including $\mathrm{NO}_{x}$ and its oxidation products) in the boundary layer over the United States and to estimate the export of these species from the U.S. boundary layer to the global atmosphere. Model results are evaluated with year-round observations for $\mathrm{O}_{3}, \mathrm{CO}$, and $\mathrm{NO}_{y}$ species at nonurban sites. A seasonal transition from $\mathrm{NO}_{x}$ to hydrocarbon-limited conditions for $\mathrm{O}_{3}$ production over the eastern United States is found to take place in the fall, with the reverse transition taking place in the spring. The mean $\mathrm{NO}_{x} / \mathrm{NO}_{y}$ molar ratio in the U.S. boundary layer in the model ranges from 0.2 in summer to 0.6 in winter, in accord with observations, and reflecting largely the seasonal variation in the chemical lifetime of $\mathrm{NO}_{x}$. Formation of hydroxy organic nitrates during oxidation of isoprene, followed by decomposition of these nitrates to $\mathrm{HNO}_{3}$, is estimated to account for $30 \%$ of the chemical sink of $\mathrm{NO}_{x}$ in the U.S. boundary layer in summer. Model results indicate that peroxyacylnitrates (PANs) are most abundant in the U.S. boundary layer in spring ( $25 \%$ of total $\mathrm{NO}_{y}$ ), reflecting a combination of active photochemistry and low temperatures. About $20 \%$ of the $\mathrm{NO}_{x}$ emitted from fossil fuel combustion in the United States in the model is exported out of the U.S. boundary layer as $\mathrm{NO}_{x}$ or PANs (15\% in summer, $25 \%$ in winter). This export responds less than proportionally to changes in $\mathrm{NO}_{x}$ emissions in summer, but more than proportionally in winter. The annual mean export of $\mathrm{NO}_{x}$ and PANs from the U.S. boundary layer is estimated to be $1.4 \mathrm{Tg} \mathrm{N} \mathrm{yr}^{-1}$, representing an important source of $\mathrm{NO}_{x}$ on the scale of the northern hemisphere troposphere. The eventual $\mathrm{O}_{3}$ production in the global troposphere due to the exported $\mathrm{NO}_{x}$ and PANs is estimated to be twice as large, on an annual basis, as the direct export of $\mathrm{O}_{3}$ pollution from the U.S. boundary layer. Fossil fuel combustion in the United States is estimated to account for about $10 \%$ of the total source of $\mathrm{O}_{3}$ in the northern hemisphere troposphere on an annual basis.
\end{abstract}

\section{Introduction}

Fossil fuel combustion accounts for about $50 \%$ of the total emission of nitrogen oxides $\left(\mathrm{NO}_{x}=\mathrm{NO}+\mathrm{NO}_{2}\right)$ to the atmosphere [Intergovernmental Panel on Climate Change, (IPCC), 1995]. This anthropogenic source could have a major influence on the global budget of tropospheric $\mathrm{O}_{3}$, considering that $\mathrm{O}_{3}$ production in the troposphere is limited primarily by the supply of $\mathrm{NO}_{x}$ [Chameides et al., 1992]. A moderating factor is the nonlinear dependence of $\mathrm{O}_{3}$ production on $\mathrm{NO}_{x}$. The number of $\mathrm{O}_{3}$ molecules produced per molecule of $\mathrm{NO}_{x}$ oxidized to $\mathrm{HNO}_{3}\left(\mathrm{O}_{3}\right.$ production efficiency) decreases rapidly as the $\mathrm{NO}_{x}$ concentration

\footnotetext{
${ }^{1}$ Now at Department of Civil and Environmnetal Engineering, Stanford University, Stanford, California.

${ }^{2}$ Now at National Center for Atmospheric Research, Boulder, Colorado.

${ }^{3}$ Now at School of Earth and Atmospheric Sciences, Georgia Institute of Technology, Atlanta, Georgia.

Copyright 1998 by the American Geophysical Union.

Paper number 97JD03126.

0148-0227/98/97JD-03126\$09.00
}

increases [Liu et al., 1987]. Most of the $\mathrm{NO}_{x}$ emitted by fossil fuel combustion is oxidized within the boundary layer of industrial continents, where $\mathrm{NO}_{x}$ concentrations are high and hence the $\mathrm{O}_{3}$ production efficiency is low. An important factor determining the global influence of fossil fuel combustion on $\mathrm{O}_{3}$ is the amount of $\mathrm{NO}_{x}$ exported out of the continental boundary layer and hence available to produce $\mathrm{O}_{3}$ with high efficiency in the remote atmosphere [Jacob et al., 1993a, b]. The export of $\mathrm{NO}_{x}$ may be facilitated by the formation within the continental boundary layer of peroxyacetylnitrate (PAN) and other peroxyacylnitrates from the oxidation of nonmethane hydrocarbons (NMHCs). These organic nitrates can be exported out of the boundary layer and serve as reservoirs for $\mathrm{NO}_{x}$ in the remote troposphere [Crutzen, 1979; Singh, 1987], in contrast to $\mathrm{HNO}_{3}$ which is mainly removed by deposition.

We examine here the seasonal budgets of $\mathrm{O}_{3}$ and $\mathrm{NO}$, species (including $\mathrm{NO}_{x}$ and its oxidation products) in the boundary layer over the United States and assess the implications for the export of $\mathrm{NO}_{y}$ species and $\mathrm{O}_{3}$ to the global atmosphere. The United States is responsible for $-30 \%$ of global $\mathrm{NO}_{x}$ emissions from fossil fuel combustion [Benkovitz et al, 1996]. Our analysis is based on a three-dimensional, continental-scale photochemical model for North America. A companion study by Horowitz et al. [this issue] uses a similar model to investigate in detail how summertime NMHC chemistry, involving in particular 
the biogenic hydrocarbon isoprene, affects the chemical cycling of $\mathrm{NO}_{\mathrm{y}}$ and the resulting export out of the boundary layer.

Several previous papers have examined the export of $\mathrm{NO}_{\text {, }}$ from North America. Logan [1983] estimated that $40 \%$ of $\mathrm{NO}_{x}$ emitted from North America is exported as $\mathrm{NO}_{y}$, based on a balance between $\mathrm{NO}_{x}$ emission inventories and measured or inferred $\mathrm{NO}_{y}$ deposition fluxes. Similar percentages were reported by Galloway et al. [1984] using a climatological analysis of winds across the east coast of the continent, and by Kasibhatla et al. [1993] using a global three-dimensional model for $\mathrm{NO}_{y}$. These analyses could not resolve the speciation of the exported NO, nor did they determine seasonal variations. From a tropospheric chemistry perspective it is crucial to distinguish between the export of $\left(\mathrm{NO}_{x}+\right.$ organic nitrates), which contributes to $\mathrm{O}_{3}$ production in the remote troposphere, and the export of $\mathrm{HNO}_{3}$ which generally does not lead to regeneration of $\mathrm{NO}_{x}$. Jacob et al. [1993b] estimated that $6 \%$ of $\mathrm{NO}_{x}$ emitted in the United States is exported as $\mathrm{NO}_{x}$ from the U.S. boundary layer in summer, but they did not account properly for the export of organic nitrates nor did they consider other seasons besides summer.

The model analysis presented in this paper accounts for the speciation of $\mathrm{NO}_{y}$ and investigates seasonal variations of the export. We describe the model in section 2 and evaluate it with observations in section 3. Seasonal variations in the chemical regime of the U.S. boundary layer are discussed in section 4 , and budgets for $\mathrm{NO}_{y}$ species are constructed in section 5 . The contribution of fossil fuel combustion in North America to global tropospheric $\mathrm{O}_{3}$ is examined in section 6.

\section{Model Description}

\subsection{General}

We use an improved version of the continental-scale photochemical model originally presented by Jacob et al. [1993a]. Our model solves the three-dimensional continuity equations for 21 chemical tracers (Table 1) over a domain including North America and large portions of the neighboring oceans (Figure 1). Winds, convective mass fluxes, and other meteorological fields are from a 1-year simulation with a general circulation model (GCM) developed at the Goddard Institute of Space Studies (GISS) [Hansen et al., 1983] and are updated every 4 hours. The grid resolution is $4^{\circ} \times 5^{\circ}$ in the horizontal, with 9 layers in the vertical along a sigma coordinate, replicating the grid of the GISS GCM (Figure 1). A nested subgrid scheme [Sillman et al., 1990a] is used to resolve nonlinear chemistry in pollution plumes from large cities and power plants. Transport of tracers is as described by Prather et al. [1987]. A previous simulation of ${ }^{222} \mathrm{Rn}$ over North America showed that the model represents the
Table 1. Chemical Tracers in the Model

\begin{tabular}{|c|c|}
\hline$\overline{\text { Tracer }}$ & Component(s) \\
\hline$O_{x}$ (odd oxygen) & $\mathrm{O}_{3}+\mathrm{NO}_{2}+2 \mathrm{NO}_{3}+3 \mathrm{~N}_{2} \mathrm{O}_{5}+\mathrm{HNO}_{4}$ \\
\hline $\mathrm{H}_{2} \mathrm{O}_{2}$ & hydrogen peroxide \\
\hline $\mathrm{NO}_{\mathrm{x}}$ & $\mathrm{NO}+\mathrm{NO}_{2}+\mathrm{NO}_{3}+\mathrm{HNO}_{2}+\mathrm{HNO}_{4}+2 \mathrm{~N}_{2} \mathrm{O}_{5}$ \\
\hline $\mathrm{HNO}_{3}$ & $\mathrm{HNO}_{3}+$ aerosol $+\mathrm{NO}_{3}^{-}$ \\
\hline PAN & peroxyacetyl nitrate \\
\hline PMN & peroxymethacryloyl nitrate \\
\hline PPN(lumped) & peroxyacyl nitrates from $\mathrm{RCHO}$ \\
\hline ISN2 (lumped) & isoprene nitrates \\
\hline R4N2 (lumped) & $\mathrm{C}_{4,5}$ alkylnitrates \\
\hline $\mathrm{CO}$ & carbon monoxide \\
\hline $\mathrm{C}_{3} \mathrm{H}_{8}$ & propane \\
\hline ALK4 (lumped) & $>C_{3}$ alkanes \\
\hline ALKE (lumped) & $>C_{2}$ alkenes, except isoprene \\
\hline $\mathrm{C}_{5} \mathrm{H}_{8}$ & isoprene \\
\hline $\mathrm{CH}_{2} \mathrm{O}$ & formaldehyde \\
\hline $\mathrm{CH}_{3} \mathrm{CHO}$ & acetaldehyde \\
\hline RCHO (lumped) & $>C_{2}$ aldehydes except MACR \\
\hline $\mathrm{CH}_{3} \mathrm{COCH}_{3}$ & acetone \\
\hline MEK (lumped) & $>C_{3}$ ketones produced from ALK4 \\
\hline MVK & methylvinylketone \\
\hline MACR & methacrolein \\
\hline
\end{tabular}

The lumping of organic compounds is done on a per carbon basis. Uniform concentrations of $1.7 \mathrm{ppmv} \mathrm{CH}_{4}$ and $1.2 \mathrm{ppbv} \mathrm{C}_{2} \mathrm{H}_{6}$ are assumed over the model domain.

ventilation of the continental boundary layer to within the constraints offered by ${ }^{222} \mathrm{Rn}$ observations, except over the eastern United States in fall where boundary layer mixing is excessive due to insufficient precipitation [Jacob and Prather, 1990; Jacob et al., 1997].

Boundary conditions for $\mathrm{O}_{3}$ concentrations at the edges of the model domain are specified as a function of altitude, latitude, and season from a climatology of ozonesonde data (J. A. Logan, manuscript in preparation, 1997). Longitudinal gradients in the ozonesonde data are small outside of the boundary layer at middle and high latitudes. Boundary conditions for $\mathrm{CO}$ are from a global three-dimensional model study (J. A. Logan, personal communication, 1997). Boundary conditions for $\mathrm{NO}_{x}, \mathrm{HNO}_{3}$, propane, butane, acetone, and $\mathrm{H}_{2} \mathrm{O}_{2}$ are specified as a function of altitude and latitude using aircraft data from the Pacific Exploratory Mission-West Phase A (PEM-West A) (September-October 1991) and Pacific Exploratory Mission-West Phase B (PEMWest B) (February-March 1994) aircraft missions over the western Pacific [Gregory and Scort, 1995a, b]; the PEM-West A and $B$ data are used as boundary conditions in June-November
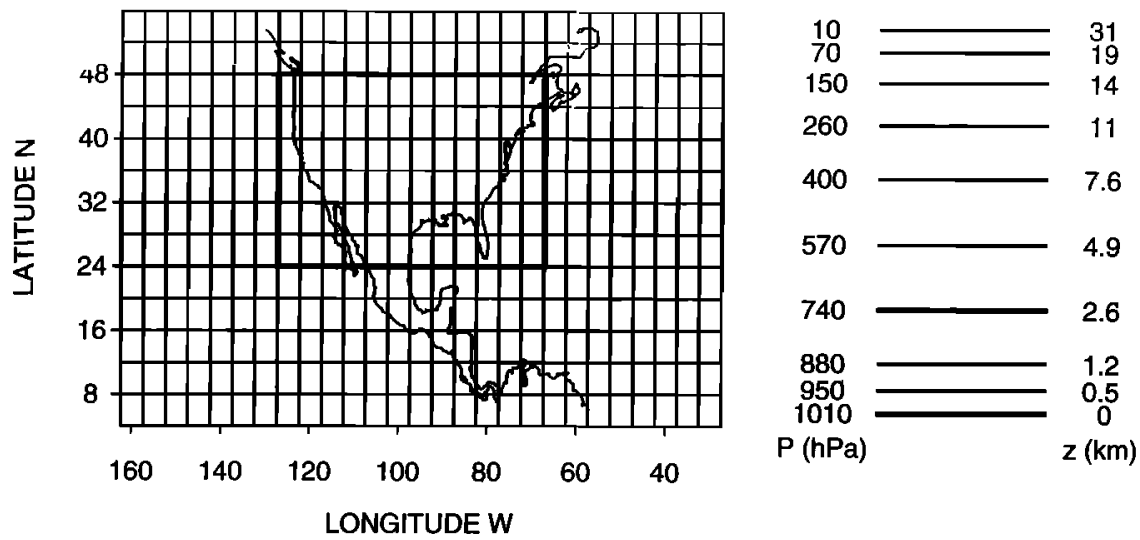

Figure 1. Model domain and grid. The edges of the figure are the boundaries of the model domain. The thick line delineates the U.S. boundary layer as defined in the paper for regional budget analyses. 
and December-May, respectively. Boundary conditions for PAN during June-November are from PEM-West A. The PAN concentrations measured by Singh et al. [1997] at northern midlatitudes during PEM-West $\mathrm{B}$ range from about 500 parts per trillion by volume (pptv) in the lower troposphere to about $200 \mathrm{pptv}$ at $500 \mathrm{hPa}$, considerably higher than the wintertime measurements of Perros [1994] over the western North Atlantic during the TROPOZ II aircraft mission which indicate a PAN concentration range of 50-100 pptv for the same latitudes. Singh et al. [1997] point out that the PEM-West B data for PAN could have been unusually affected by the outflow of continental pollution. As discussed in section 3, we can achieve in the model a good simulation of the Perros [1994] data and also of the wintertime data from a Canadian site by scaling down the model boundary condition for PAN during December-May by a factor of 10 from the PEM-West B data, essentially suppressing advection of PAN from outside the model domain; we choose to do so in the standard simulation. For all tracers other than those discussed above, we adopt low concentrations (1 pptv) as boundary conditions.

The simulations are conducted for 13 months, starting from the boundary conditions as initial conditions. The first month (May) is used for decay of the initial conditions (ventilation of the model domain requires less than 1 month). We focus our analysis on the last 12 months of simulation.

\subsection{Chemistry}

Chemical changes in tracer concentrations are computed with a fast Gear solver [Jacobson and Turco, 1994] applied to a photochemical mechanism for $\mathrm{O}_{3}-\mathrm{NO}_{1}$-hydrocarbon chemistry including detailed oxidation schemes for $\mathrm{C}_{1-4}$ alkanes, propene, and isoprene. The mechanism draws on compilations by DeMore et al. [1994] for inorganic and methane chemistry and by Atkinson et al. [1992] and Atkinson [1994] for NMHC chemistry; thermal decomposition rates for PAN and PPN are from Grosjean et al. [1994], and the chemistry of organic peroxy radicals $\left(\mathrm{RO}_{2}\right)$ includes new data from Kirchner and Stockwell [1996] and Maricq and Szente [1996a, b]. A discussion of the NMHC chemistry and a full listing of the isoprene oxidation mechanism are presented by Horowitz et al. [this issue]. Aqueous phase radical chemistry in clouds is ignored as it appears to have negligible effect on $\mathrm{O}_{3}$ [Liang and Jacob, 1997]. Reactions in aerosols are calculated as a first-order loss defined by a reaction probability on the aerosol surface [Dentener and Crutzen, 1993]. We adopt a reaction probability of 0.1 for the hydrolysis of $\mathrm{N}_{2} \mathrm{O}_{5}$ to $\mathrm{HNO}_{3}$ [Mozurkewich and Calvert, 1988] and for the conversion to $\mathrm{HNO}_{3}$ of hydroxy organic nitrates produced by oxidation of alkenes and isoprene [Shepson et al., 1996; P. B. Shepson, personal communication, 1996]. We also adopt a reaction probability of 0.1 for scavenging of $\mathrm{HO}_{2}$ and hydroxy $\mathrm{RO}_{2}$ radicals by aerosols. The spatial and temporal distribution of aerosols is based on a sulfate mass simulation by Chin et al. [1996] using the same GISS GCM meteorological fields. We compute the aerosol surface area from the sulfate mass in each gridbox by assuming that the aerosol particles are aqueous solutions of $\mathrm{NH}_{4} \mathrm{HSO}_{4}$ with a dry radius of $0.1 \mu \mathrm{m}$ and liquid $\mathrm{H}_{2} \mathrm{O}$ determined from thermodynamic equilibrium (Raoult's law) at the local relative humidity.

Actinic fluxes are computed hourly on the basis of the solar zenith angle, the GCM cloud optical depths (updated every 4 hours), and the total $\mathrm{O}_{3}$ columns specified as a function of latitude and month [Spivakovsky et al., 1990]. The radiation code uses a 6-stream approximation for the Rayleigh scattering atmosphere [Logan et al., 1981]. Clouds are treated as reflective surfaces with reflectivities specified at four different altitudes to match the GCM vertical distribution of cloud optical depths [Spivakovsky et al., 1990]. A light-absorbing aerosol is included with an optical depth of 0.1 at $310 \mathrm{~nm}$ varying inversely with wavelength.

The chemical mechanism used in this study is identical to that of Horowitz et al. [this issue] except for the aerosol uptake of
$\mathrm{HO}_{2}$, hydroxy $\mathrm{RO}_{2}$ radicals, and hydroxy organic nitrates. Horowitz et al. [this issue] assumed reaction probabilities in aerosols of unity for $\mathrm{HO}_{2}$ and zero for hydroxy $\mathrm{RO}_{2}$ radicals and hydroxy organic nitrates; whereas we assume 0.1 for all these species. Because of the added aerosol sink for hydroxy $\mathrm{RO}_{2}$ radicals and hydroxy organic nitrates in our model, concentrations in surface air over the eastern United States in summer are 5-10 parts per billion by volume (ppbv) lower than obtained by Horowitz et al. [this issue].

\subsection{Emissions and Deposition}

Anthropogenic emissions of $\mathrm{NO}_{x}, \mathrm{CO}$, and NMHCs from North America are based on 1990 national inventories for the United States [U.S. Environmental Protection Agency (EPA), 1995] and Canada [Environment Canada, 1995], with spatial distributions from the National Acid Precipitation Assessment Program (NAPAP) [U.S. EPA, 1989]. Alkanes with $\geq 4 \mathrm{C}$ atoms are emitted as ALK4 (Table 1) on a per-carbon basis, and alkenes with $\geq 3 \mathrm{C}$ atoms are similarly emitted as ALKE on a per-carbon basis. Seasonal variations of $\mathrm{NO}_{x}$ and $\mathrm{CO}$ emissions are less than $10 \%$ [U.S. NAPAP, 1991] and are neglected. A $10 \%$ seasonal amplitude is applied to emissions of anthropogenic NMHCs, with maximum in summer and minimum in winter [U.S. NAPAP, 1991]. Anthropogenic emissions from Central and South America are as given by Jacob et al. [1993a] and do not vary with time of year.

Biogenic emission of isoprene is calculated hourly using the emission algorithm of Guenther et al. [1995] as modified by (Y. Wang et al., Global simulation of tropospheric $\mathrm{O}_{3}-\mathrm{NO}_{x}-$ hydrocarbon chemistry, 1, Model formulation, submitted to Journal of Geophysical Research, 1997a) (hereinafter referred to as Wang et al., submitted manuscript, 1997a) and applied to the surface-type map of Olson [1992] with $0.5^{\circ} \times 0.5^{\circ}$ resolution. The emission varies with local temperature and light intensity and with the local leaf area index (LAI) which is updated monthly based on satellite observations of the global vegetation index (GVI). Seasonal observations of isoprene emission from forests in Colorado and Massachusetts indicate a time lag between the onset of photosynthesis and isoprene emission, with isoprene emission starting in early June and shutting off in late September [Monson et al., 1995; Goldstein et al., 1996]. In the model we restrict isoprene emission north of $40^{\circ} \mathrm{N}$ to the June-September time window. Biogenic emissions of other alkenes and acetone are scaled to that of isoprene with emission factors on a carbon basis of 0.051 for alkenes [Goldstein et al., 1996] and 0.025 for acetone (Wang et al., submitted manuscript, 1997a).

Dry deposition fluxes of $\mathrm{O}_{3}, \mathrm{NO}_{x}$, peroxyacylnitrates, hydroxy organic nitrates, $\mathrm{HNO}_{3}, \mathrm{H}_{2} \mathrm{O}_{2}$, and $\mathrm{CH}_{2} \mathrm{O}$ are calculated locally using a big-leaf resistance-in-series model (Wang et al., submitted manuscript, 1997a) applied to the Olson [1992] surface-type map. The aerodynamic resistances are computed from archived GCM data for surface wind, solar irradiance at the surface, and nighttime cloud cover [Jacob et al., 1993a]. The surface resistances vary with surface type, species type [Wesely, 1989], temperature, light intensity, monthly updated LAI, and snow cover in winter. Hydroxy organic nitrates are highly soluble in water [Shepson et al., 1996] and are assumed to deposit like $\mathrm{HNO}_{3}$. Wet deposition of highly water-soluble tracers $\left(\mathrm{HNO}_{3}\right.$, hydroxy organic nitrates, $\left.\mathrm{H}_{2} \mathrm{O}_{2}\right)$ is computed as described by Balkanski et al. [1993] from the GCM wet convective mass fluxes and synoptic precipitation fields; $100 \%$ scavenging of these tracers in precipitating convective updrafts is assumed.

\section{Evaluation with Observations}

The model is intended to simulate a typical meteorological year, rather than any given year; evaluation with observations must therefore focus on seasonal statistics. Horowitz et al. [this 
Table 2. Observations Used for Model Evaluation

\begin{tabular}{|c|c|c|}
\hline Species & Site & Length of Record \\
\hline \multirow{4}{*}{$\mathrm{O}_{3}$ at surface } & EPA/AIRS network & $1980-1995^{\mathrm{a}}$ \\
\hline & Harvard Forest, Massachusetts & $1990-1994^{b}$ \\
\hline & Bermuda & Oct 1988-Sept $1991^{\mathrm{C}}$ \\
\hline & Shenandoah Natl. Park, Virginia & Oct $1988-O c t 1989^{d}$ \\
\hline \multirow[t]{2}{*}{$\mathrm{O}_{3}$ vertical profile } & Boulder, Colorado & Dec 1984-Dec 1993 \\
\hline & Wallops Island, Virginia & Jan $1980-A p r ~ 1993^{\circ}$ \\
\hline $\mathrm{NO}_{x}$ & Harvard Forest, Massachusetts & $1990-1994^{b}$ \\
\hline \multirow[t]{2}{*}{$\mathrm{NO}_{y}$} & Harvard Forest, Massachusetts & $1990-1994^{b}$ \\
\hline & Shenandoah Natl. Park, Virginia & Oct 1988 -Oct $1989^{d}$ \\
\hline PAN & Kejimkujik Natl. Park, Nova Scotia & Jun 1984-Apr $1989^{f}$ \\
\hline \multirow[t]{2}{*}{$\mathrm{CO}$} & Harvard Forest, Massachusetts & $1990-1995^{b}$ \\
\hline & Shenandoah Natl. Park, Virginia & Oct $1988-O c t 1989^{d}$ \\
\hline $\mathrm{NO}_{y}$ deposition flux & Harvard Forest, Massachusetts & $1990-1994^{\mathrm{b}, \mathrm{g}}$ \\
\hline
\end{tabular}

\footnotetext{
${ }^{a}$ Long-term observations at 223 nonurban sites in the United States reported by the Aeronometric Information Retrieval Service (AIRS) and analyzed by Fiore et al. [1997]. Nonurban sites are selected on the basis of local $\mathrm{NO}_{x}$ emission densities, as described by Fiore et al. [1997]. We compute seasonal mean 1300-1600 local time (LT) concentrations for each site and individual years; from there we derive mean concentrations for each $4^{\circ} \times 5^{\circ}$ model grid square (Figure 1) in individual years by averaging the means for all sites in the grid square. Mean concentrations in the $4^{\circ} \times 5^{\circ}$ grid square for the 1980-1995 period are then obtained by averaging the grid square means for the individual years, and standard deviations are computed from the interannual variability.

b Five-year continuous record of hourly observations at Harvard Forest, Massachusetts. The concentrations of $\mathrm{O}_{3}, \mathrm{NO}_{x}$ and $\mathrm{NO}_{3}$ are as reported by Munger et al. (submitted manuscript, 1997), and those of $\mathrm{CO}$ are unpublished data from J.W. Munger. Mean concentrations at 12-16 LT are computed for each month of individual years, excluding fresh pollution plumes diagnosed by $\mathrm{NO}_{x} / \mathrm{NO},>0.8 \mathrm{~mol} / \mathrm{mol}$. Monthly means are then averaged over the 5 years of the record, and standard deviations are computed from the interannual variability.

${ }^{c}$ From Oltmans and Levy [1992]. Concentrations are 24-hour averages.

d From Poulida et al. [1991] and Doddridge et al. [1992]. The observations are at $1100 \mathrm{~m}$ altitude on a mountain ridge. We select observed concentrations at 0000-0400 LT for comparison with the model in order to minimize the effect of upslope winds in observations.

e Ozonesonde observations reported by J.A. Logan ( manuscript in preparation, 1997). Monthly means and standard deviations are for all observations within that month for the given time period. Seasonal mean concentrations are calculated from the appropriate monthly means.

' From Sirots and Bottenheim [1995]. Concentrations are 24-hour averages.

Including both wet deposition of $\mathrm{NO}_{3}^{-}$and dry deposition of $\mathrm{NO}_{y}$ measured separately (Munger et al., submitted manuscript, 1997).
}

issue] presented a detailed evaluation of the model for summer. Surface air concentrations of $\mathrm{O}_{3}$ over the south central United States in summer were overestimated by $10-30 \mathrm{ppbv}$, due to insufficient ventilation of the region in the GCM by maritime air from the Gulf of Mexico. The observed $\mathrm{O}_{3}$ versus $\mathrm{CO}$ and $\mathrm{O}_{3}$ versus $\left(\mathrm{NO}_{y}-\mathrm{NO}_{x}\right)$ correlations and corresponding slopes were closely reproduced, implying a good simulation of the $\mathrm{O}_{3}$ production efficiency. The model simulated to within about $30 \%$ the observed median summer concentrations of $\mathrm{NO}_{x}, \mathrm{PAN}, \mathrm{HNO}_{3}$, and $\mathrm{NO}_{y}$ at nonurban sites in North America and captured to within $10 \%$ the observed speciation of $\mathrm{NO}_{y}$ among $\mathrm{NO}_{x}, \mathrm{PAN}$, and $\mathrm{HNO}_{3}$ at individual sites.

We extend here the evaluation presented by Horowitz et al. [this issue] to investigate seasonal variations. For this purpose, we use time series of observations at non-urban sites that are at least 1 year long (Table 2). Unless otherwise indicated, we limit our comparison to early aftemoon when surface air measurements are most likely to be representative of a deep mixed layer that can be resolved with the model. The concentration statistics sampled in the model exclude the pollution plumes resolved with the subgrid plumes scheme [Sillman et al., 1990a] and are thus representative of rural conditions.

\subsection{Ozone}

Figure 2 compares the simulated and observed distributions of $\mathrm{O}_{3}$ concentrations in surface air over the United States for different seasons. The observations are from the EPA Aeronometric Information Retrieval Service (AIRS), as described in Table 2. The highest observed concentrations are over the eastern United States and southern California in summer, and these are captured by the model to within $10 \mathrm{ppbv}$. The model overestimates $\mathrm{O}_{3}$ by 10-20 ppbv in the south central United States in summer and fall, a discrepancy discussed by Horowitz et al. [this issue]. The regional depletion of $\mathrm{O}_{3}$ over the northeastern United States in winter, found both in the model and in the observations, reflects destruction of $\mathrm{O}_{3}$ by $\mathrm{NO}$ emissions; oxidation of $\mathrm{NO}$ to $\mathrm{HNO}_{3}$ via hydrolysis of $\mathrm{N}_{2} \mathrm{O}_{5}$ in aerosols (the principal sink of $\mathrm{NO}_{x}$ in winter) consumes 1.5 molecules $\mathrm{O}_{3}$ per molecule of NO oxidized.

To assess the ability of the model to reproduce the spatial variance of $\mathrm{O}_{3}$ concentrations over the United States, we show in Figure 3 a statistical summary of simulated versus observed concentrations in $4^{\circ} \times 5^{\circ}$ grid squares for the data in Figure 2 . The least squares correlation coefficient $r^{2}$ between model and observations ranges from 0.55 to 0.65 depending on season. The model has a mean bias of -2 to +3.5 ppbv.

Simulated and observed seasonal vanations of $\mathrm{O}_{3}$ concentrations are compared in Figure 4. The model captures the springsummer maximum over the United States, although the seasonal peak in the model over the eastern United States is shifted to the end of the summer (August) reflecting the seasonal peak in GCM temperatures [Jacob et al., 1993a]. The amplitude of the seasonal cycle is larger in the eastern than in the westem United States, both in the observations [Logan, 1989] and in the model; this regional difference is driven by the high $\mathrm{NO}_{x}$ emissions in the east, which promote $\mathrm{O}_{3}$ formation in summer but act to deplete $\mathrm{O}_{3}$ in winter. Also shown in Figure 4 is a comparison of model results to observations for Bermuda [Oltmans and Levy, 1992]. The model reproduces well the observed seasonal cycle characterized by a spring maximum and summer minimum. 


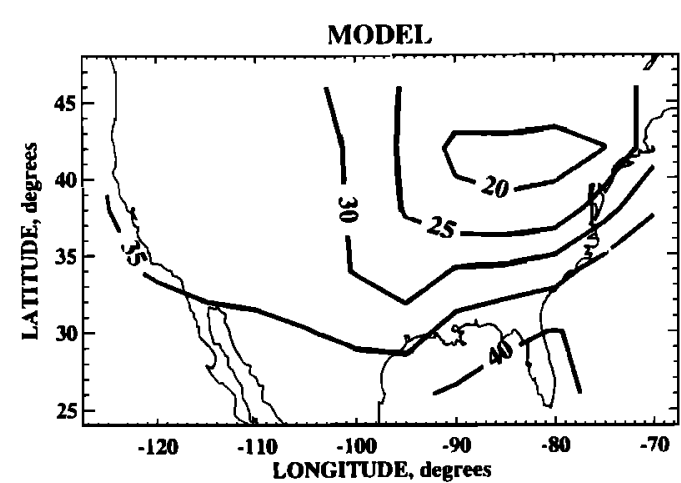

DJF

OBSERVED

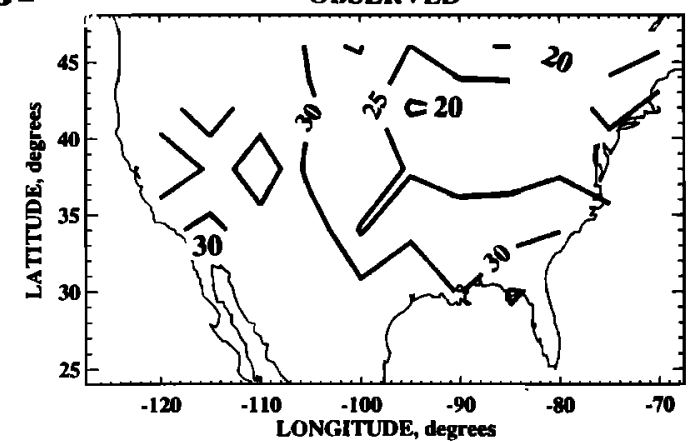

MAM
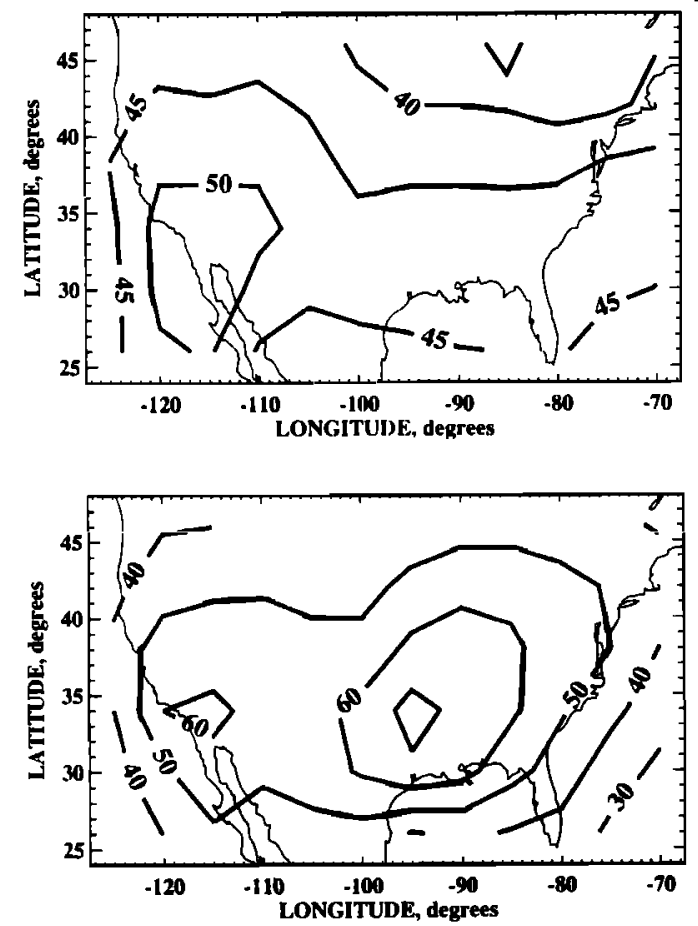

JJA
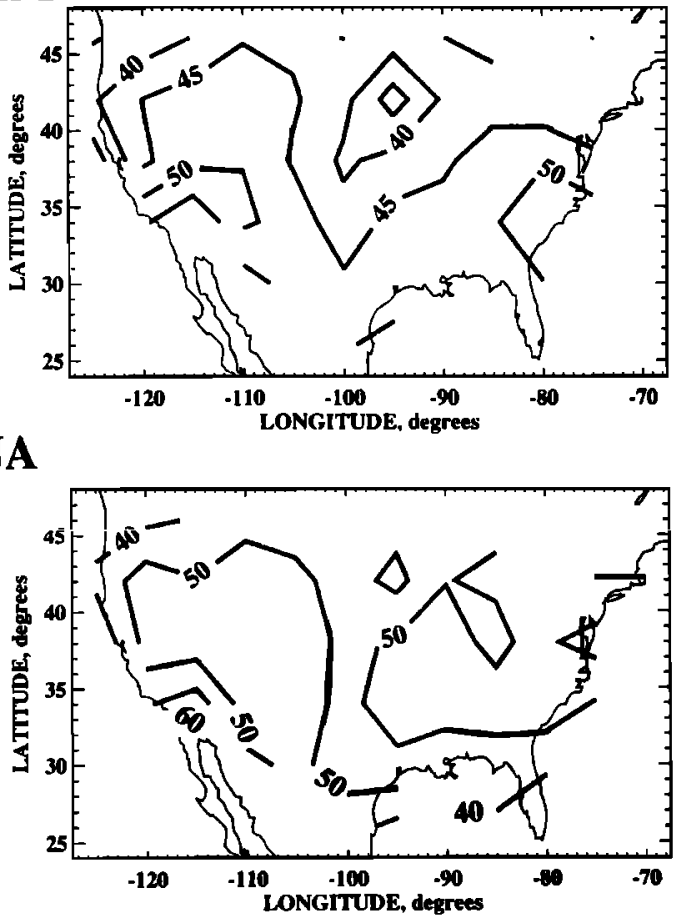

SON

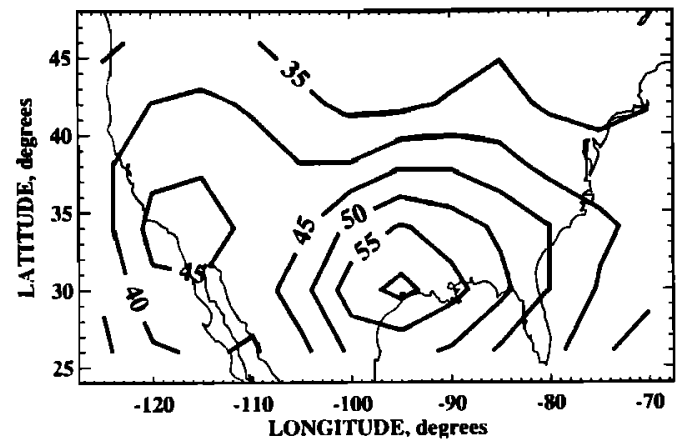

Figure 2. Mean afternoon (1300-1600 local time) $\mathrm{O}_{3}$ concentrations (ppbv) in surface air over the United States in different seasons. Model results (left panels) are compared to 1980-1995 observations from the EPA Aeronometric Information Retrieval Service (AIRS). Contours are at $5 \mathrm{ppbv}$ intervals except for the summer panel where they are at 10 ppbv intervals.

Advection of boundary conditions, chemistry, and deposition all play a role in shaping the distribution of $\mathrm{O}_{3}$ in the model. In order to isolate these influences we conducted two sensitivity simulations: (1) a "no-chemistry" simulation where $\mathrm{O}_{3}$ is solely controlled by transport from the boundaries and deposition; (2) a "zero- $\mathrm{NO}_{x}$ " simulation where no $\mathrm{NO}_{x}$ is emitted from the model domain. In the latter simulation, advection of $\mathrm{NO}_{x}$ and PAN from the boundaries maintains a background $\mathrm{NO}_{x}$ concentration of 2-50 pptv in the boundary layer over the United States. Comparison of these sensitivity simulations to the standard simulation in Figure 4 shows that regional production makes an important contribution to $\mathrm{O}_{3}$ concentrations in surface air over the United States in all seasons except winter. Ozone concentrations in the zero- $\mathrm{NO}_{x}$ simulation are $20-40 \mathrm{ppbv}$, with little seasonal varia- 


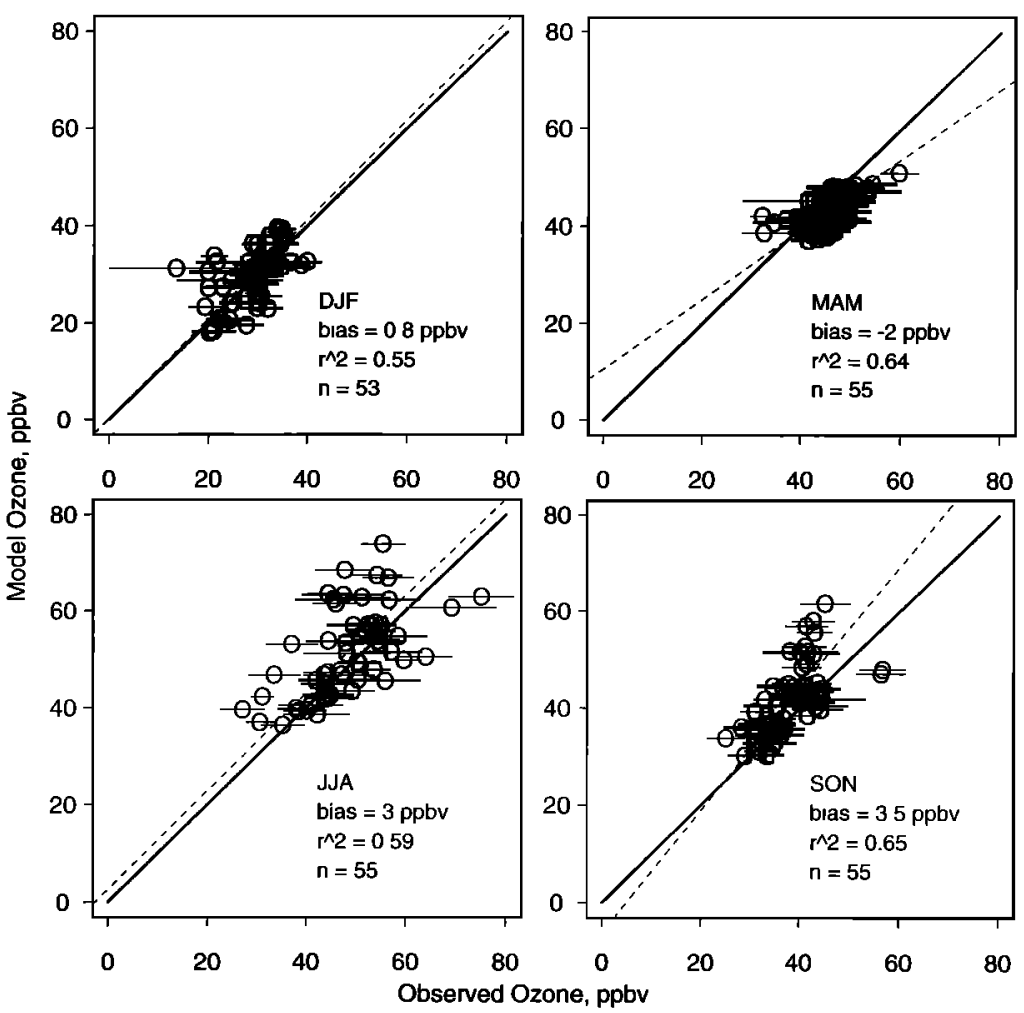

Figure 3. Scatterplots of simulated versus observed seasonal mean $\mathrm{O}_{3}$ concentrations (ppbv) in surface air over the United States at 1300-1600 local time. Data are shown for all $4^{\circ} \times 5^{\circ}$ grid squares where EPA/AIRS data are available [Fiore et al., 1997]. When several EPA/AIRS sites are present in one grid square, the data are first averaged over all sites for a given year and then over the 16-year record; the corresponding standard deviations (horizontal bars) are defined by the interannual variability of the seasonal mean concentrations for individual years. Also shown on the figure are the 1:1 line (solid lines), the least-squares regression line calculated with the reduced major axis method (dashed lines), the least squares correlation coefficient $r^{2}$, and the mean bias defined as $1 / n$ $\sum\left(\left[\mathrm{O}_{3}\right]_{\text {model }}-\left[\mathrm{O}_{3}\right]_{\text {obs }}\right)$ for all points on the plot.

tion. The summer minimum at Bermuda is caused by photochemical loss.

Simulated vertical profiles of $\mathrm{O}_{3}$ concentrations in different seasons are compared in Figure 5 to the ozonesonde data from Wallops Island, Virginia and Boulder, Colorado. The model underestimates $\mathrm{O}_{3}$ concentrations over Wallops Island by 10-20 ppbv in summer; other seasons are simulated better. Regional production of $\mathrm{O}_{3}$ from $\mathrm{NO}_{x}$ emissions in the United States, as diagnosed by the difference between the standard and zero- $\mathrm{NO}_{x}$ simulations, accounts for more than $10 \mathrm{ppbv}$ of $\mathrm{O}_{3}$ up to $700 \mathrm{hPa}$ altitude over Wallops Island in all seasons except winter. In winter, $\mathrm{NO}_{x}$ emissions cause a 5 ppbv depletion of simulated $\mathrm{O}_{3}$ concentrations near the surface; surface depletion is also apparent in the observations. Over Boulder, simulated $\mathrm{O}_{3}$ concentrations in winter are largely controlled by advection of boundary conditions, but in other seasons there is an important contribution from regional photochemical production extending up to $500 \mathrm{hPa}$.

\section{2. $\mathrm{NO}_{\mathrm{y}}$ Species and $\mathrm{CO}$}

Figure 6 compares simulated and observed seasonal variations of $\mathrm{NO}_{x}, \mathrm{NO}_{y}$, and $\mathrm{CO}$ concentrations at Harvard Forest, Massachusetts. Also shown is the $\mathrm{NO}_{x} / \mathrm{NO}_{y}$ concentration ratio. The hourly observations used to construct the monthly means were filtered to remove fresh pollution plumes as diagnosed by $\mathrm{NO}_{x} / \mathrm{NO}_{y}>0.8 \mathrm{~mol} / \mathrm{mol}$ (in the model, pollution plumes are effectively removed by the subgrid plumes scheme). Model and observations show summer minima and winter maxima for all species, due in part to seasonal variations in mixing depth $[\mathrm{Holz}$ - worth, 1967], and also in the case of $\mathrm{NO}_{x}$ to the longer lifetime in winter (J. W. Munger et al., Regional budgets for nitrogen oxides from continental sources: Factors affecting oxidation and deposition, submitted to Journal of Geophysical Research, 1997) (hereinafter referred to as Mu;nger et al., submitted manuscript, 1997). The strong seasonal variation of the $\mathrm{NO}_{x} / \mathrm{NO}_{y}$ concentration ratio is captured by the model and largely reflects the seasonal variation in the lifetime of $\mathrm{NO}_{x}$ (see discussion in section 5). The model underestimates $\mathrm{NO}_{y}$ concentrations in spring and fall, a problem which we attribute to precipitation anomalies over the eastern United States in the GCM [Jacob and Prather, 1990]. The GCM spring is wetter than normal, resulting in efficient scavenging of $\mathrm{HNO}_{3}$ and thus relatively low $\mathrm{NO}_{y}$ concentrations but high $\mathrm{NO}_{x} / \mathrm{NO}$, ratios (Figure 6). Conversely, the GCM fall is drier than normal, resulting in a deep boundary layer and low concentrations of both $\mathrm{NO}_{\mathrm{r}}$ and $\mathrm{CO}$ (note that $\mathrm{CO}$ is underestimated in the fall but not in the spring).

Figure 7 compares simulated and observed seasonal variations of NO, and CO concentrations at Shenandoah National Park, Virginia (1100 m altitude). Concentrations of $\mathrm{NO}_{y}$, show a summer minimum and winter maximum, both in the model and in observations, as at Harvard Forest. Spring and summer $\mathrm{NO}_{y}$ concentrations in the model are too low by a factor of 2 . Observed concentrations of $\mathrm{CO}$ also show a summer minimum and winter maximum, except for high values in July-August which are neither captured by the model nor seen in the Harvard Forest observations. Poulida et al. [1991] attributed the high summer $\mathrm{CO}$ values in the observations to the effect of isoprene 

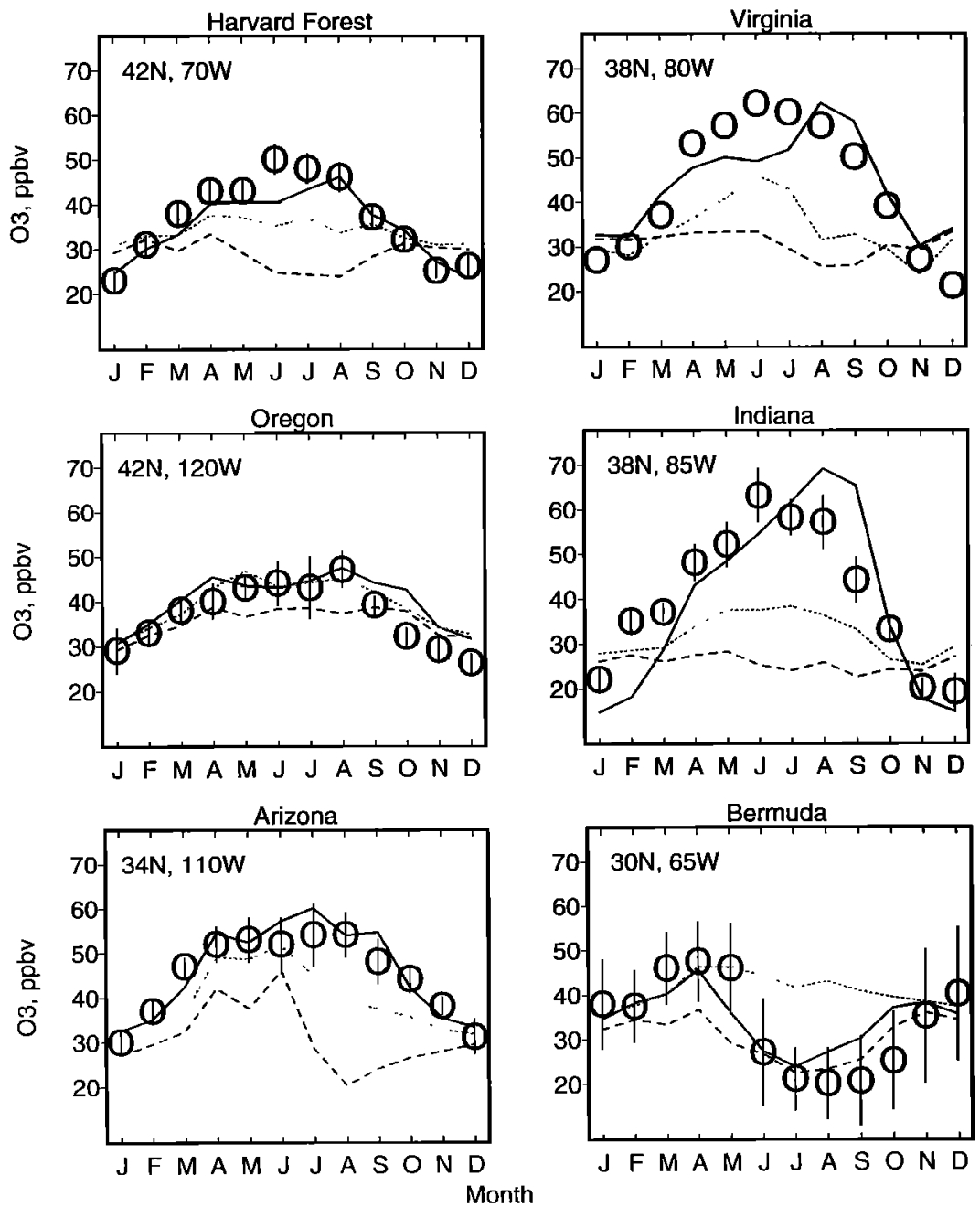

Figure 4. Seasonal variation of simulated and observed monthly mean $\mathrm{O}_{3}$ concentrations (ppbv) in surface air at 1300-1600 local time. Observed monthly means for 1980-1995 are plotted as open circles; the vertical bars are the interannual standard deviations. Model results are shown for the standard simulation (solid lines), the no-chemistry simulation (dotted lines), and the zero-NO $\mathrm{NO}_{x}$ simulation (dashed lines). The observations are from the EPA/AIRS network averaged over $4^{\circ} \times 5^{\circ}$ grid squares (the center of the grid square is indicated), except for Harvard Forest (Munger et al., submitted manuscript, 1997) and Bermuda [Oltmans and Levy, 1992]. Concentrations at Bermuda are 24-hour averages.

oxidation, but the implied isoprene emission would be exceedingly high. We find in the model that isoprene oxidation contributes less than $30 \mathrm{ppbv} \mathrm{CO}$ at the site in summer (results from a simulation without isoprene emission are shown as dashed lines in Figure 7).

To our knowledge, the only year-round record for PAN concentrations in non-urban air in North America is from Kejimkujik National Park, Nova Scotia [Sirois and Bottenheim, 1995]. Comparison between model and observations is shown in Figure 8. The seasonal maximum is in February-March in the observations and March-May in the model; the model overestimates PAN concentrations in all seasons except winter. Day-to-day variability in the model is considerable, as shown by the dashed lines (standard deviations of daily concentrations). This variability reflects the contrast in influence at the site between air masses with elevated PAN advected from the eastern United States and air masses with low PAN advected from the north. Horowitz et al. [this issue] showed that the model reproduces to within $30 \%$ the observed PAN concentrations over the eastern United States in summer, with no evident bias. We explain the excessive PAN in the model at Kejimkujik as caused by too frequent transport of air from the eastern United States to the site in summer, a problem previously noted by Chin et al. [1996] in their simulation of summertime sulfate over eastern Canada using the same meteorological fields.

As discussed in section 2, the model boundary condition for PAN concentrations during December-May was scaled down by a factor of 10 from the PEM-West B observations. This allows model results to match roughly not only the wintertime PAN concentrations observed at Kejimkujik but also the TROPOZ-II aircraft observations of PAN by Perros [1994] over the western North Atlantic in January, which ranged from about $100 \mathrm{pptv}$ in the lower troposphere to $50 \mathrm{pptv}$ at $500 \mathrm{hPa}$. We find that use of the PAN concentrations from PEM-West B flights as a model boundary condition would lead to an overestimate of the wintertime Kejimkujik and TROPOZ-II data by factors of 2 to 4 .

\subsection{Nitrate Deposition}

We compare in Figure 9 the simulated and observed seasonal variations of nitrate deposition fluxes (separately for wet and dry) 

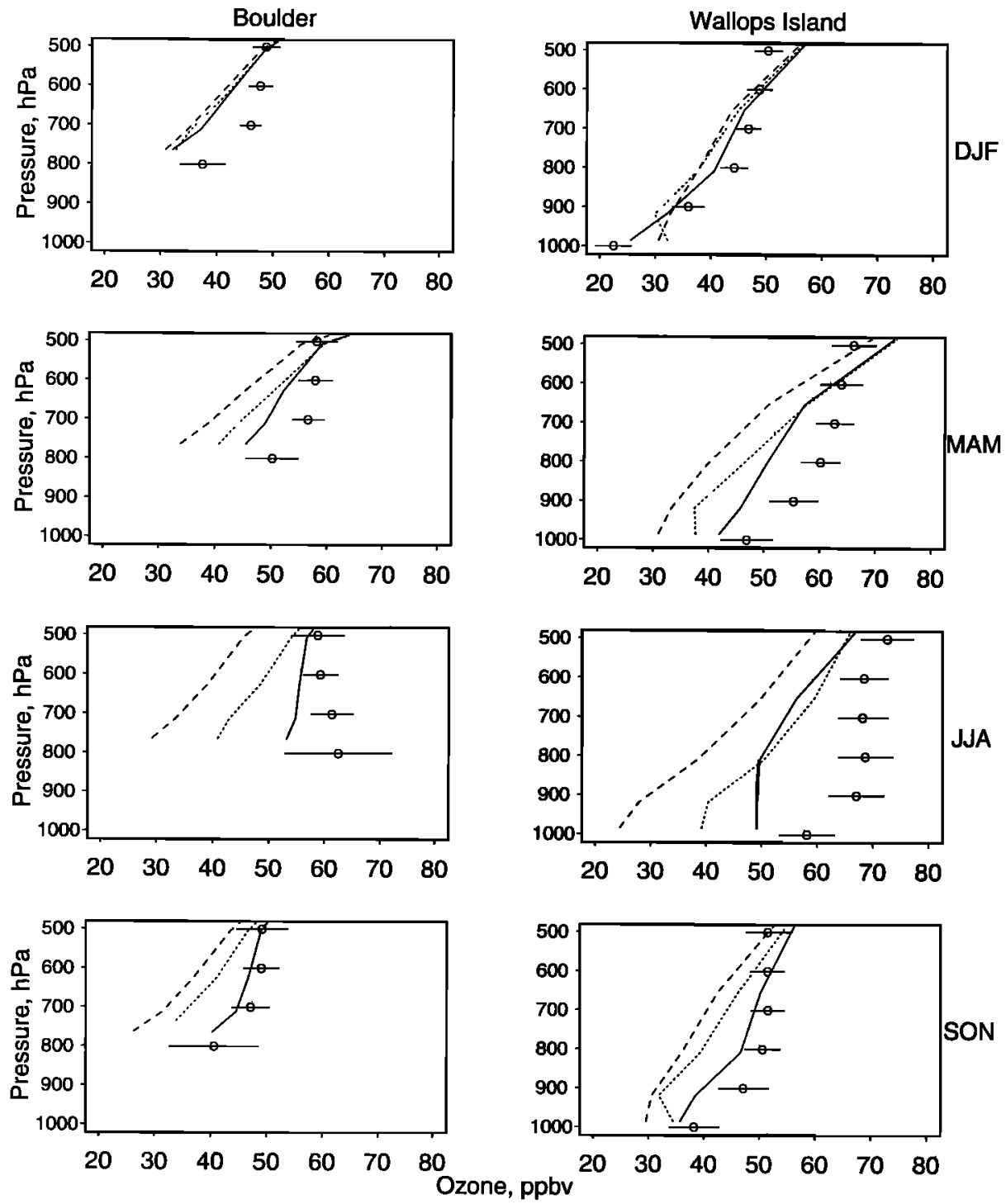

Figure 5. Seasonally averaged vertical profiles of $\mathrm{O}_{3}$ concentrations over Boulder, Colorado ( $835 \mathrm{hPa}$ surface) and Wallops Island, Virginia. Observations (Table 2) are plotted as open circles; horizontal bars represent the interannual standard deviations. Model results are shown for the standard simulation (solid lines), the no-chemistry simulation (dotted lines), and the zero- $\mathrm{NO}_{x}$ simulation (dashed lines).

at Harvard Forest. The observations show a weak winter minimum which Munger et al. (submitted manuscript, 1997) attributed to a lesser abundance of $\mathrm{HNO}_{3}$, the main depositing form of $\mathrm{NO}_{y}$, during that season. The model reproduces to within $20 \%$ the mean deposition fluxes of $\mathrm{NO}_{y}$ in individual seasons, except in the fall when the model is too low by almost a factor of 2. The fall anomaly is partly due to low GCM precipitation in the region, as discussed previously. The drought not only suppresses removal by wet deposition, but also increases boundary layer mixing and hence slows down dry deposition as well. We find that hydroxy organic nitrates formed from the oxidation of isoprene with a $12 \%$ yield [Horowitz et al., this issue] contribute $23 \%$ of the total summertime deposition of nitrate at Harvard Forest in the model. These organic nitrates decompose rapidly to $\mathrm{NO}_{3}^{-}$in aqueous solution (P. B. Shepson, personal communication, 1996) and hence would be measured as $\mathrm{NO}_{3}^{-}$in precipitation samples.

\section{Seasonal Variation in Photochemical Regime}

Theoretical arguments and limited observations suggest that a seasonal transition from $\mathrm{NO}_{\boldsymbol{x}}$ - to NMHC-limited conditions for $\mathrm{O}_{3}$ production should take place over the eastern United States in September because of decreasing UV radiation and the end of isoprene emission [Jacob et al., 1995]. We examined this issue in our three-dimensional model by conducting sensitivity studies with either $\mathrm{NO}_{x}$ or NMHC emissions reduced by a factor of 2 over the model domain (the reduction of NMHC emissions was applied to both anthropogenic and biogenic sources). Changes in the simulated seasonal mean $\mathrm{O}_{3}$ concentrations are shown in Figure 10. In summer, $\mathrm{O}_{3}$ production is strongly $\mathrm{NO}_{x}$-limited, as noted in previous model studies [Trainer et al., 1987; Sillman et al., 1990b; McKeen et al., 1991; Jacob et al., 1993b]; halving $\mathrm{NO}_{x}$ emissions decreases $\mathrm{O}_{3}$ concentrations by $10-20$ ppbv over most of the United States, while halving NMHC emissions decreases $\mathrm{O}_{3}$ concentrations by less than 5 ppbv. In winter, by 

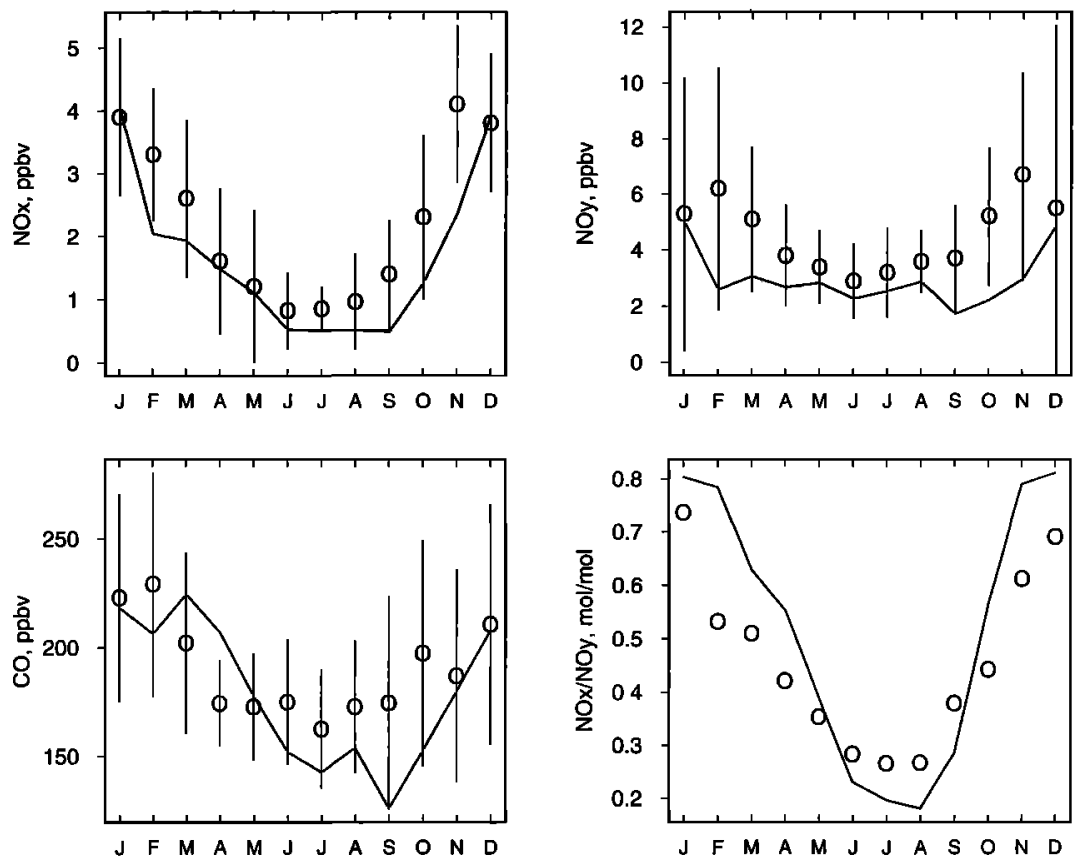

Figure 6. Seasonal variations of monthly mean concentrations of $\mathrm{NO}_{x}, \mathrm{NO}_{y}$, and $\mathrm{CO}$ and $\mathrm{NO}_{x} / \mathrm{NO}_{\text {, concentration }}$ ratios at Harvard Forest, Massachusetts, at 1200-1600 local time. Observations for 1990-1994 (Table 2) are plotted as open circles; the vertical bars are the interannual standard deviations. Model results are plotted as solid lines.

contrast, halving $\mathrm{NO}_{x}$ emissions causes an increase in $\mathrm{O}_{3}$ concentrations, particularly in the northeast, because conversion of $\mathrm{NO}_{x}$ to $\mathrm{HNO}_{3}$ by hydrolysis of $\mathrm{N}_{2} \mathrm{O}_{5}$ represents a major sink for $\mathrm{O}_{3}$ in that season. The largest sensitivity to NMHC emissions is in the fall (September-November) in the eastern United States, when photochemistry is still active but mostly NMHC-limited, as proposed by Jacob et al. [1995].

\section{Seasonal Budget of $\mathrm{NO}_{\mathbf{y}}$ Species}

Table 3 summarizes the model budgets for the U.S. boundary layer of $\mathrm{NO}$, emitted by fossil fuel combustion within the region in different seasons. The U.S. boundary layer is defined as the region extending horizontally over the area delineated by thick lines in Figure 1 and vertically from the surface to the top of model layer 3 (about $740 \mathrm{hPa}$ ). The $\mathrm{NO}$, budget in the zero-NO simulation was subtracted from that in the standard simulation in order to remove the small influence of $\mathrm{NO}$, advected from outside the region; the correction is less than $20 \%$ for most terms in the Table.

We see from Table 3 that the NO, pool is dominated by $\mathrm{NO}_{x}$, $\mathrm{HNO}_{3}$, and PAN in all seasons. Organic nitrates other than PAN contribute $10 \%$ of $\mathrm{NO}_{y}$ in summer and $5 \%$ in other seasons. The fraction of $\mathrm{NO}_{\text {, present as }} \mathrm{NO}_{x}$ is maximum in winter (60\%) and minimum in summer $(20 \%)$, while that present as $\mathrm{HNO}_{3}$ is minimum in winter $(25 \%)$ and maximum in summer $(55 \%)$. In spring and fall, $\mathrm{NO}_{x}$ and $\mathrm{HNO}_{3}$ each account for $30-45 \%$ of $\mathrm{NO}_{3}$. The contribution of PAN to $\mathrm{NO}_{y}$ is largest in spring (20\%) and smallest in winter (6\%). Although the lifetime of PAN is longest in winter because of the low temperatures, photochemical oxidation of NMHCs is then at its seasonal minimum and hence there is little production of PAN. The high PAN concentrations in spring reflect a combination of low temperatures and active photochemistry. Oxidation of isoprene provides the dominant source of PAN in summer [Horowitz et al., this issue].

The mean seasonal variation of the $\mathrm{NO}_{x} / \mathrm{NO}$, ratio in the U.S. boundary layer in the model is similar to that previously shown for Harvard Forest (Figure 6). Munger et al. (submitted manuscript, 1997) proposed that this seasonal variation is driven primarily by seasonal changes in the lifetime of $\mathrm{NO}_{x}$, and we find in the model that this is indeed the case. The model lifetime of $\mathrm{NO}_{x}$ in the U.S. boundary layer ranges from 0.3 days in summer to 1.2 days in winter; the model lifetime of $\mathrm{HNO}_{3}$ varies less, ranging from 0.5 day in spring to 1.1 days in fall (Table 3). As previously discussed, most of the seasonality in the $\mathrm{HNO}_{3}$ lifetime in the model is driven by the spring maximum and fall minimum of precipitation over the eastern United States in the GCM year, whereas climatological data show little seasonal variation of precipitation in this region. During summer, formation of hydroxy organic nitrates by oxidation of isoprene followed by rapid decomposition of these organic nitrates to $\mathrm{HNO}_{3}$ accounts for $30 \%$ of total $\mathrm{HNO}_{3}$ formation and hence represents an important sink pathway for $\mathrm{NO}_{x}$. In winter, production of $\mathrm{HNO}_{3}$ is dominated by hydrolysis of $\mathrm{N}_{2} \mathrm{O}_{5}$ in aerosols, which is limited by the rate of $\mathrm{NO}_{3}$ production from the $\mathrm{NO}_{2}+\mathrm{O}_{3}$ reaction.

On an annual basis, $30 \%$ of the $\mathrm{NO}_{x}$ emitted in the United States is exported out of the U.S. boundary layer as NO, $(25 \%$ in summer, 35\% in winter). Our estimate of the annual mean export is consistent with previous studies [Logan, 1983; Galloway et al., 1984; Kasibhatla et al., 1993]. The seasonal variation in $\mathrm{NO}_{3}$ export reflects the seasonal variation of the $\mathrm{HNO}_{3} \mathrm{NO}$, concentration ratio in the U.S. boundary layer, as $\mathrm{HNO}_{3}$ is the main depositing component of $\mathrm{NO}_{y}$; a larger fraction of $\mathrm{HNO}_{3}$ implies a shorter lifetime of $\mathrm{NO}_{y}$ against deposition and hence less $\mathrm{NO}_{3}$ export.

From a global tropospheric chemistry perspective, export of $\mathrm{NO}$. as $\mathrm{HNO}_{3}$ is of limited interest because most of this $\mathrm{HNO}_{3}$ will be removed eventually by deposition. The critical components of the exported $\mathrm{NO}_{y}$ are $\mathrm{NO}_{x}$, which drives $\mathrm{O}_{3}$ production in the remote troposphere, and peroxyacylnitrates (PANs), which eventually decompose to $\mathrm{NO}_{x}$; we refer to the sum of these two $\mathrm{NO}_{y}$ components as "NO+ PANs." We find in the model that most of the $\mathrm{NO}_{y}$ exported from the U.S. boundary layer is in the form of $\mathrm{NO}_{x}+$ PANs, $60-80 \%$ depending on season (Table 

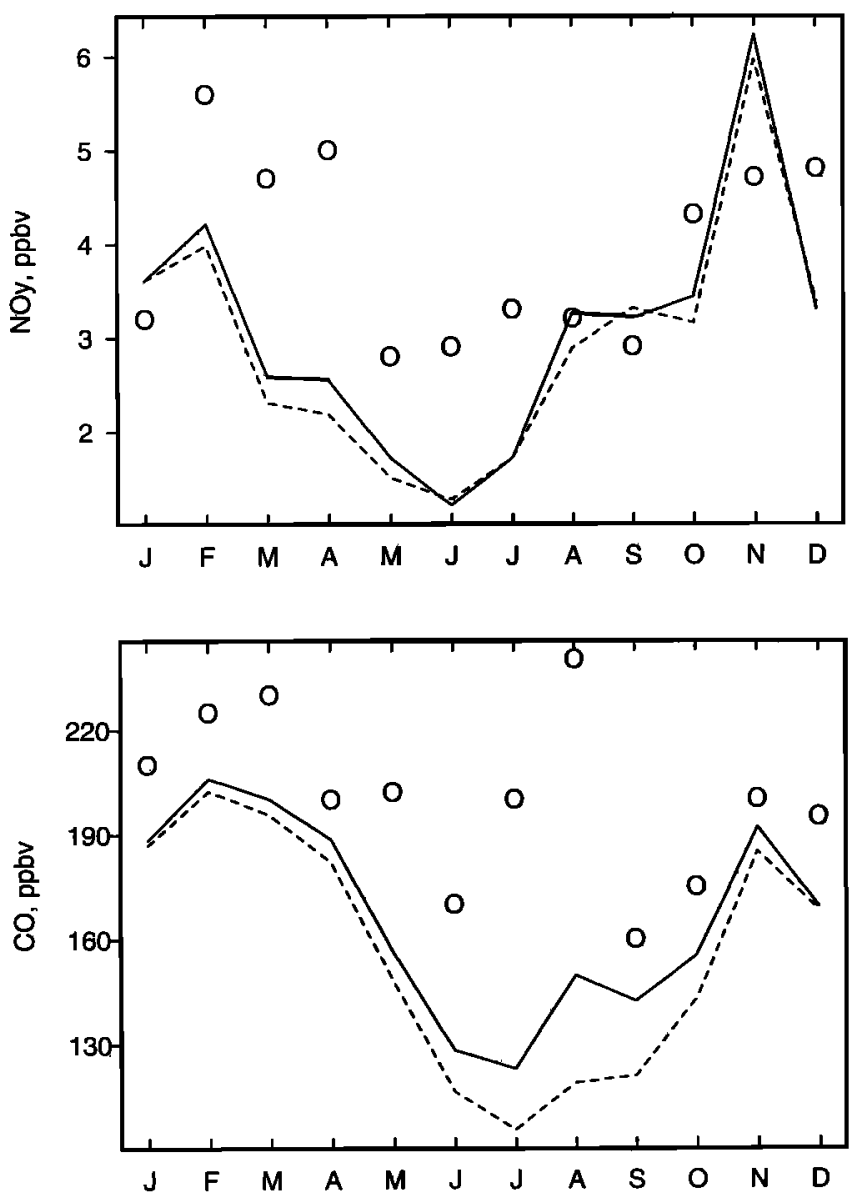

Figure 7. Seasonal variation of monthly mean concentrations of $\mathrm{NO}$, and $\mathrm{CO}$ at Shenandoah National Park, Virginia (mountain ridge site, $1100 \mathrm{~m}$ altitude). The observations were sampled at $0000-4000$ LT to avoid the effect of daytime upslope flow [Poulida et al., 1991] while model results are 24-hour averages sampled in model layer 2 (Figure 1). Observations (Table 2) are plotted as open circles, and model results are plotted as solid lines. The observations are for 1 year only, hence no interannual standard deviations are shown. The dashed lines show model results for a simulation without emission of isoprene.

3). Although $\mathrm{NO}_{x}+$ PANs account for only $40 \%$ of $\mathrm{NO}_{y}$ in the U.S. boundary layer in summer, export of $\mathrm{NO}_{y}$ in that season takes place principally by wet convection (Figure 11 [see also Jacob et al. 1993b; Thompson et al. 1994]) during which $\mathrm{HNO}_{3}$ is efficiently scavenged. By contrast, in winter most of the export is by advection northward and eastward in the lower troposphere (Figure 11), and the speciation of $\mathrm{NO}_{y}$ in the exported air reflects more closely the speciation in the U.S. boundary layer. The $\mathrm{NO}_{x} /$ PANs concentration ratio in the exported air ranges from 1 in summer to 5 in winter, reflecting the partitioning in the boundary layer air (Table 3).

To investigate the response in the export of $\mathrm{NO}_{x}+\mathrm{PANs}$ to changes in $\mathrm{NO}_{x}$ emissions, we conducted simulations where $\mathrm{NO}_{x}$ emissions in the U.S. boundary layer domain were increased or decreased by a factor of 2 . Results are shown in Figure 12. In summer when photochemistry is $\mathrm{NO}_{x}$-limited, increasing $\mathrm{NO}_{x}$ emission leads to an increase in $\mathrm{OH}$ concentrations and hence a decrease in the $\mathrm{NO}_{x}$ lifetime; the export of $\mathrm{NO}_{x}+$ PANs responds less than proportionally to the change in emission. By contrast, in winter when photochemistry is NMHC-limited, doubling $\mathrm{NO}_{x}$ emissions increases the lifetime of $\mathrm{NO}_{x}$ (because of lower $\mathrm{O}_{3}$ concentrations, slowing down the rate of the $\mathrm{NO}_{2}+\mathrm{O}_{3}$ reaction), and the export of $\mathrm{NO}_{x}+$ PANs responds more than proportionally.

\section{Global Implications for Ozone}

The yearly export of $\mathrm{NO}_{x}+$ PANs out of the U.S. boundary layer in the model is $1.4 \mathrm{Tg} \mathrm{N} \mathrm{yr}^{-1}\left(0.27 \mathrm{Gmol} \mathrm{d}^{-1}\right)$, which can be compared to northern hemisphere estimates of $\mathrm{NO}_{x}$ sources from lightning (1.7 $\mathrm{Tg} \mathrm{N} \mathrm{yr}^{-1}$ ) ([Wang et al., submitted manuscript, 1997a) and aircraft $\left(0.4 \mathrm{Tg} \mathrm{N} \mathrm{yr}^{-1}\right)$ [Baughcum et al., 1996]. Export of pollution from the United States is clearly a major source of $\mathrm{NO}_{x}$ to the northern hemisphere troposphere, in all seasons.

To estimate the eventual source of $\mathrm{O}_{3}$ from the exported $\mathrm{NO}_{x}$ + PANs, we calculated from our model the $\mathrm{O}_{3}$ production efficiency (OPE) in the U.S. boundary layer and in the band of adjacent grid boxes (Figure 11). The OPE is defined as the gross number of odd oxygen $\left(\mathrm{O}_{x}\right)$ molecules produced from a $\mathrm{NO}_{x}$ molecule before it is oxidized to $\mathrm{HNO}_{3}$, which is then assumed to be removed by deposition [ $\mathrm{Liu}$ et al., 1987]. We calculate the OPE for a region in the model as the ratio of $\mathrm{O}_{x}$ to $\mathrm{HNO}_{3}$ production averaged over the region. The OPE ranges from 3 in winter to 16 in summer in the U.S. boundary layer and from 35 in winter to 61 in summer in the free troposphere (Figure 11). By applying the OPE for each region to the corresponding export fluxes of $\mathrm{NO}_{x}+$ PANs (Figure 11), we estimate a source of $\mathrm{O}_{3}$ to the global troposphere ranging from $5 \mathrm{Gmol} \mathrm{d}^{-1}$ in winter to $11 \mathrm{Gmol}$ $\mathrm{d}^{-1}$ in summer, for an annual average of $8.0 \mathrm{Gmol} \mathrm{d}^{-1}$. A more accurate estimate would require a global simulation.

The above source of $\mathrm{O}_{3}$ can be compared to the direct export of $\mathrm{O}_{3}$ pollution from the United States. A model budget for $\mathrm{O}_{3}$ (Table 4) shows that the U.S. boundary layer is a net sink for $\mathrm{O}_{3}$ in winter and spring and a net source in summer and fall. This budget can be viewed as the difference between the import of background $\mathrm{O}_{3}$ from outside the U.S. boundary layer and the export of pollution $\mathrm{O}_{3}$ produced within the region. We obtain a budget for pollution $\mathrm{O}_{3}$ in the model (Table 4) as the difference between results from the standard simulation and from the zero$\mathrm{NO}_{x}$ simulation (where only the import of background $\mathrm{O}_{3}$ is considered). The export of pollution $\mathrm{O}_{3}$ from the U.S. boundary layer is thus defined analogously to that of fossil fuel NO, discussed in the previous section. Of the $7.9 \mathrm{Gmol} \mathrm{d}^{-1}$ of pollution $\mathrm{O}_{3}$ produced within the U.S. boundary layer on an annual mean basis, $35 \%$ is chemically consumed within the boundary layer (mostly by the $\mathrm{O}^{1} \mathrm{D}+\mathrm{H}_{2} \mathrm{O}$ reaction), $15 \%$ is deposited, and $50 \%$ is exported. Export of pollution $\mathrm{O}_{3}$ from the U.S. boundary layer

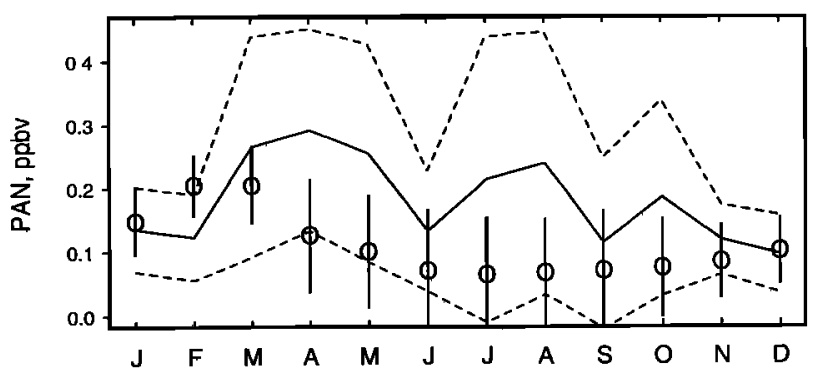

Figure 8. Seasonal variation of monthly mean concentrations of PAN at Kejimkujik National Park, Nova Scotia. Observations (Table 2) are shown as open circles, with interannual standard deviations as vertical lines. Model results are shown as solid lines, with standard deviations of daily concentrations shown as dashed lines. 


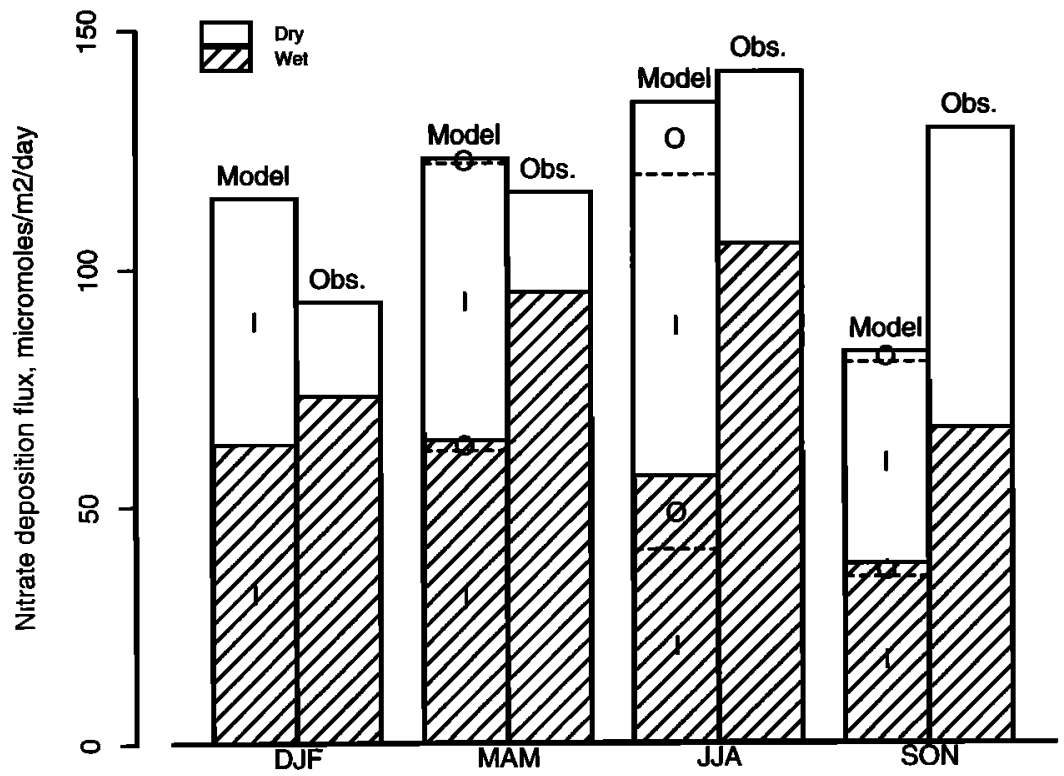

Figure 9. Simulated and observed wet and dry deposition fluxes of $\mathrm{NO}_{3}^{-}$at Harvard Forest, Massachusetts in different seasons. Model results are shown separately for $\mathrm{NO}_{3}^{-}$produced by inorganic (I) and organic (O) pathways, as described in the text and in Table 3. Reference for the observations is given in Table 2.

Table 3 Budget of fossil fuel combustion $\mathrm{NO}_{1}$ in the U S boundary layer

\begin{tabular}{|c|c|c|c|c|}
\hline Season & Summer (JJA) & Fall (SON) & Winter (DJF) & Spring (MAM) \\
\hline \multicolumn{5}{|l|}{ Concentration, ppbv } \\
\hline $\mathrm{NO}_{x}$ & 0.21 & 0.51 & 0.80 & 0.36 \\
\hline PAN & 0.13 & 0.11 & 0.08 & 0.20 \\
\hline PMN & 0.012 & 0.006 & 0.003 & 0.007 \\
\hline PPN (lumped) & 0.023 & 0.020 & 0.003 & 0.024 \\
\hline Isoprene nitrates & 0.028 & 0.020 & 0.001 & 0.005 \\
\hline Alkylnitrates & 0.015 & 0.015 & 0.015 & 0.031 \\
\hline $\mathrm{HNO}_{3}$ & 0.55 & 0.60 & 0.35 & 0.29 \\
\hline Total $\mathrm{NO}_{r}$ & 1.0 & 1.3 & 1.3 & 0.9 \\
\hline \multicolumn{5}{|l|}{ Lifetime, days } \\
\hline $\mathrm{NO}_{x}$ & 027 & 0.64 & 1.2 & 0.47 \\
\hline PAN & 0.086 & 0.23 & 0.95 & 0.47 \\
\hline $\mathrm{HNO}_{3}$ & 0.93 & 1.1 & 0.67 & 0.50 \\
\hline $\mathrm{NO}_{x}$ emission, Gmol d $\mathrm{d}^{-1}$ & 1.34 & 1.34 & 1.34 & 1.34 \\
\hline \multicolumn{5}{|l|}{ Dry deposition, Gmol d ${ }^{-1}$} \\
\hline $\mathrm{NO}_{x}$ & 0.077 & 0.094 & 0.064 & 0.092 \\
\hline PANs & 0.030 & 0.015 & 0.0039 & 0.020 \\
\hline $\mathrm{RNO}_{3}$ & 0.034 & 0.023 & 0.0022 & 0.010 \\
\hline $\mathrm{HNO}_{3}(\mathrm{I})$ & 0.35 & 0.39 & 0.39 & 0.41 \\
\hline $\mathrm{HNO}_{3}(\mathrm{O})$ & 0.12 & 0.051 & 0.0099 & 0.037 \\
\hline Total dry deposition & 0.62 & 0.57 & 0.47 & 0.57 \\
\hline \multicolumn{5}{|l|}{ Wet deposition, Gmol d ${ }^{-1}$} \\
\hline $\mathrm{HNO}_{3}(\mathrm{I})$ & 0.23 & 0.30 & 0.39 & 0.37 \\
\hline $\mathrm{HNO}_{3}(\mathrm{O})$ & 0.14 & 0.048 & 0.016 & 0.052 \\
\hline Total wet deposition & 0.37 & 0.35 & 0.41 & 0.42 \\
\hline \multicolumn{5}{|l|}{ Export, Gmol d ${ }^{-1}$} \\
\hline $\mathrm{NO}_{x}$ & 0.10 & 0.14 & 0.27 & 0.15 \\
\hline PANs & 0.122 & 0.108 & 0.054 & 0.12 \\
\hline $\mathrm{RNO}_{3}$ & 0.027 & 0.022 & 0.0090 & 0.019 \\
\hline $\mathrm{HNO}_{3}(\mathrm{I})$ & 0.073 & 0.13 & 0.11 & 0.061 \\
\hline $\mathrm{HNO}_{3}(\mathrm{O})$ & 0.026 & 0.016 & 0.0021 & 0.0036 \\
\hline Total export & 0.35 & 0.42 & 0.46 & 0.35 \\
\hline
\end{tabular}

All quantities are 3-month averages for the U.S. boundary layer extending horizontally over the area delineated by thick lines in Figure 1 and vertically to the top of model layer 3 (about $740 \mathrm{hPa}$ ). The budgets are for $\mathrm{NO}_{3}$ emitted by fossil fuel combustion within the region, as determined by subtracting the background NO concentrations and fluxes from the zero- $\mathrm{NO}_{x}$ simulation. PANs includes PAN, PMN, and PPN; $\mathrm{RNO}_{3}$ includes isoprene nitrates and alkylnitrates. $\mathrm{HNO}_{3}(\mathrm{I})$ denotes $\mathrm{HNO}_{3}$ of inorganic origin, namely, formed from oxidation of $\mathrm{NO}_{2}$ by $\mathrm{OH}$ and hydrolysis of $\mathrm{N}_{2} \mathrm{O}_{5}$ in aerosols; $\mathrm{HNO}_{3}(\mathrm{O})$ denotes $\mathrm{HNO}_{3}$ produced by decomposition of hydroxy organic nitrates (mainly isoprene nitrates). Aerosol nitrate is lumped with $\mathrm{HNO}_{3}$ in the model. Lifetimes are defined as the concentrations divided by the sum of chemcal and deposition loss rates. JJA, June, July, and August; SON, September, October, and November, DJF, December, January, and February; MAN, March, April, and May. 

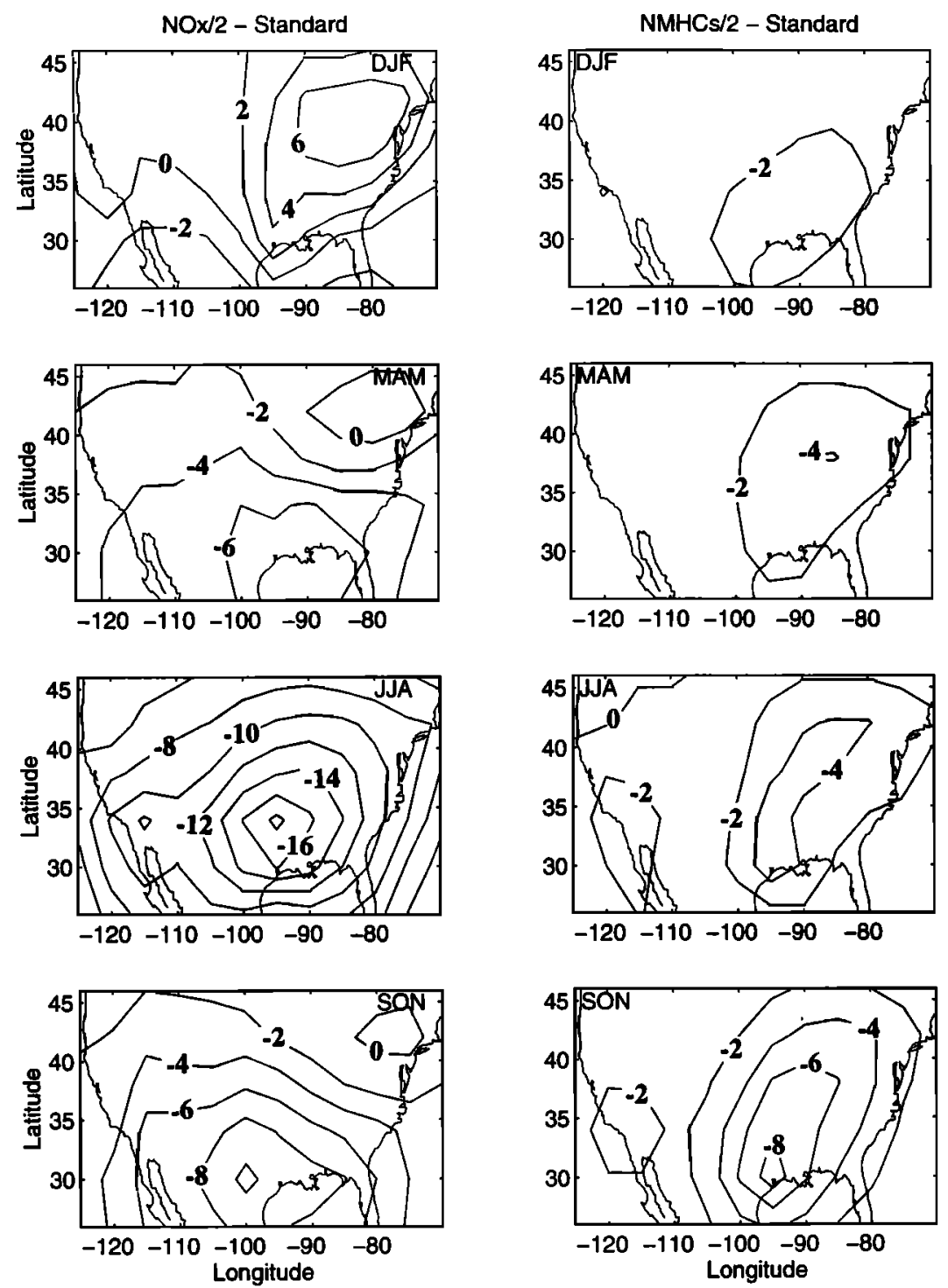

Figure 10. Simulated changes in seasonal mean afternoon $\mathrm{O}_{3}$ concentrations (ppbv) in surface air resulting from halved emissions of $\mathrm{NO}_{x}$ (left panels) or NMHCs (right panels). The reduction of NMHC emissions is applied to both anthropogenic and biogenic sources.

ranges from $1 \mathrm{Gmol} \mathrm{d}^{-1}$ in winter to $6.5 \mathrm{Gmol} \mathrm{d}^{-1}$ in summer, for an annual average of $3.8 \mathrm{Gmol} \mathrm{d}^{-1}$.

We thus find that export of U.S. pollution supplies $12 \mathrm{Gmol}$ $\mathrm{d}^{-1}$ of $\mathrm{O}_{3}$ annually to the global troposphere $\left(4 \mathrm{Gmol} \mathrm{d}^{-1}\right.$ from direct export of $\mathrm{O}_{3}, 8 \mathrm{Gmol} \mathrm{d}^{-1}$ from export of $\mathrm{NO}_{x}+$ PANs). Using an earlier version of the model, Jacob et al. [1993b] estimated a global source of $\mathrm{O}_{3}$ from export of U.S. pollution in summer of $8 \mathrm{Gmol} \mathrm{d}^{-1}$ (4 $\mathrm{Gmol} \mathrm{d}^{-1}$ from direct export of $\mathrm{O}_{3}, 4$ $\mathrm{Gmol} \mathrm{d}^{-1}$ from export of $\mathrm{NO}_{x}$, none from export of PANs). In our model the corresponding $\mathrm{O}_{3}$ source for summer is $17 \mathrm{Gmol}$ $\mathrm{d}^{-1}\left(6 \mathrm{Gmol} \mathrm{d}^{-1}\right.$ from direct export of $\mathrm{O}_{3}, 11 \mathrm{Gmol} \mathrm{d}^{-1}$ from export of $\mathrm{NO}_{x}+\mathrm{PANs}$ ). There were significant problems in the representation of $\mathrm{NO}_{y}$ chemistry in the Jacob et al. [1993b] model, including notably the simulation of PANs, which have been corrected in the present version [Horowitz et al., this issue].

The global $\mathrm{O}_{3}$ source contributed by U.S. pollution can be estimated from our model on an annual basis by adding the 8 $\mathrm{Gmol} \mathrm{d}^{-1}$ produced within the U.S. boundary layer (Table 4) to the $8 \mathrm{Gmol} \mathrm{d}^{-1}$ produced following export of $\mathrm{NO}_{x}+$ PANs, for a total of $16 \mathrm{Gmol} \mathrm{d}^{-1}$ (or $5.9 \mathrm{Tmol} \mathrm{yr}^{-1}$ ). In comparison, a global three-dimensional model study by Y. Wang et al. (Global simulation of tropospheric $\mathrm{O}_{3}-\mathrm{NO}_{x}$-hydrocarbon chemistry, 2, Model evaluation and global ozone budget, submitted to Journal of Geophysical Research, 1997b) (hereinafter referred to as Wang et al., submitted manuscript, 1997b) estimates an annual mean odd oxy-

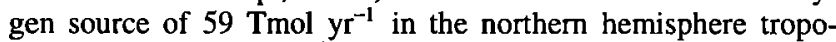

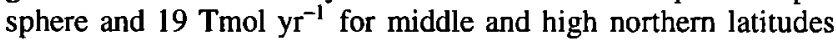
$\left(30^{\circ}-90^{\circ} \mathrm{N}\right)$. Low latitudes dominate the hemispheric $\mathrm{O}_{3}$ budget because of the large OPEs. Our results suggest that U.S. pollution makes only a small contribution to $\mathrm{O}_{3}$ on the scale of the northern hemisphere troposphere but is important on the scale of the extratropical latitudes.

\section{Conclusions}

We have used a continental-scale, three-dimensional photochemical model to investigate the budgets of $\mathrm{NO}_{4}$ species and $\mathrm{O}_{3}$ in the continental boundary layer over the United States and to 


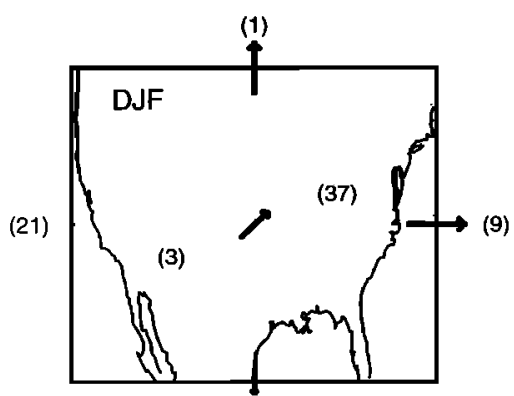

(26)

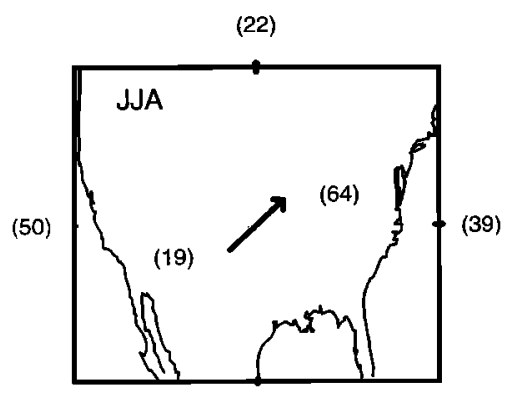

(35)

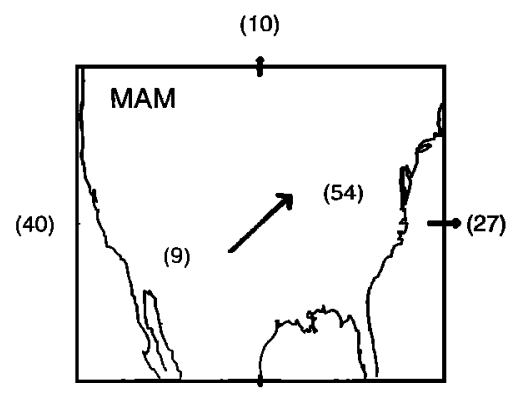

(32)

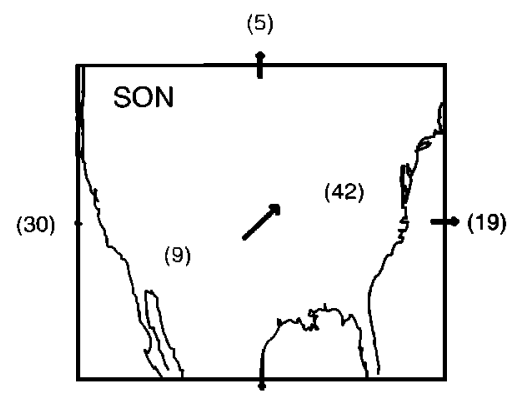

(28)

$\longrightarrow 0.1 \mathrm{Gmol}$ (NOx + PANs) /day

Figure 11. Export of $\mathrm{NO}_{x}+$ PANs from the U.S. boundary layer and related $\mathrm{O}_{3}$ production efficiency (OPE). The arrows show the seasonal mean export fluxes of $\mathrm{NO}_{x}+$ PANs from the U.S. boundary layer to the west, east, south, north, and free troposphere (above $740 \mathrm{hPa}$ ) in the model. The central arrow denotes the upward flux to the free troposphere. The lengths of the arrows are proportional to the fluxes. The numbers in parentheses are the modeled OPEs ( $\mathrm{mol} / \mathrm{mol}$ ) in the U.S. boundary layer (lower left of the central arrows), the four adjacent boundary layer regions (margins of the plots), and the free troposphere (upper right of the central arrows). The definition of OPE is given in the text.

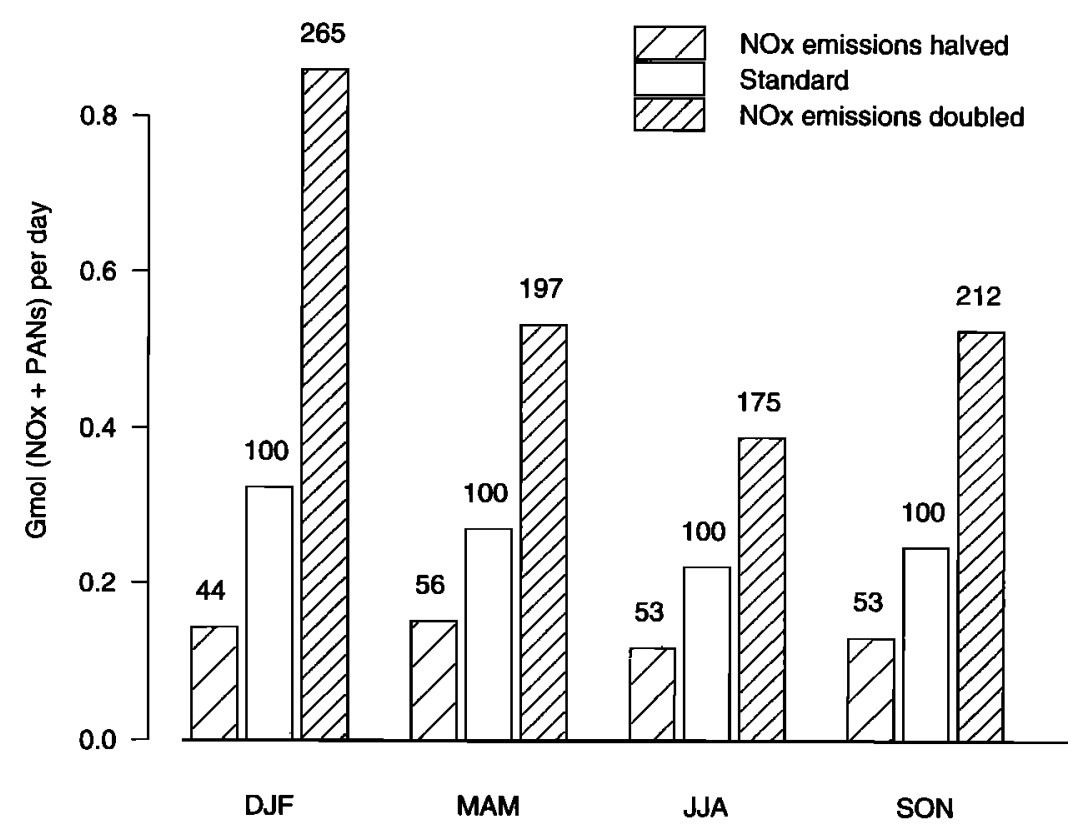

Figure 12. Seasonal mean export fluxes of $\left(\mathrm{NO}_{x}+\mathrm{PANs}\right)$ from the U.S. boundary layer in the standard simulation and in simulations with halved or doubled $\mathrm{NO}_{x}$ emissions. The percentage changes in the export fluxes for each season, relative to the standard simulation $(100 \%)$, are shown on top of the bars. 
Table 4. Seasonal budgets of ozone in the U.S. boundary layer in the model

\begin{tabular}{|c|c|c|c|c|c|}
\hline Season & $\begin{array}{l}\text { Summer(JJA), } \\
\text { Gmol d }^{-1}\end{array}$ & $\begin{array}{l}\text { Fall(SON), } \\
\text { Gmol d }^{-1} \\
\end{array}$ & $\begin{array}{l}\text { Winter(DJF), } \\
\text { Gmol d }^{-1} \\
\end{array}$ & $\begin{array}{l}\text { Spring(MAM), } \\
\text { Gmol d }^{-1}\end{array}$ & $\begin{array}{l}\text { Annual, } \\
\text { Gmol d }^{-1} \\
\end{array}$ \\
\hline \multicolumn{6}{|c|}{ Standard Simulation } \\
\hline $\mathrm{P}_{\mathrm{O}_{\mathrm{x}}}$ & 15 & 8.5 & 3.1 & 8.3 & 8.8 \\
\hline $\mathrm{L}_{\mathrm{O}_{\mathrm{x}}}$ & 8.7 & 4.6 & 2.5 & 4.8 & 5.2 \\
\hline $\mathrm{O}_{3}$ deposition & 4.7 & 2.9 & 1.4 & 3.4 & 3.0 \\
\hline $\mathrm{O}_{3}$ export & 1.8 & 1.0 & -1.0 & -0.50 & 0.33 \\
\hline $\mathrm{P}_{\mathrm{O}_{\mathrm{x}}}$ from exported & & & & & \\
\hline $\mathrm{NO}_{x}$ and PANs ${ }^{\mathrm{a}}$ & 11 & 5.9 & 4.8 & 11 & 8.2 \\
\hline \multicolumn{6}{|c|}{ Pollution Ozone $e^{b}$} \\
\hline $\mathbf{P}_{\mathbf{O}_{\mathbf{x}}}$ & 13 & 7.5 & 2.9 & 7.9 & 7.9 \\
\hline $\mathbf{L}_{\mathbf{O}_{\mathbf{x}}}$ & 4.2 & 2.7 & 1.7 & 2.4 & 2.7 \\
\hline $\mathrm{O}_{3}$ deposition & 2.5 & 1.2 & 0.075 & 1.1 & 1.2 \\
\hline $\mathrm{O}_{3}$ export & 6.5 & 3.9 & 1.0 & 3.9 & 3.8 \\
\hline
\end{tabular}

The budgets are given for odd oxygen, $O_{x}$ (Table 1), to account for the rapid interconversion between $\mathrm{O}_{x}$ species. Since $\mathrm{O}_{3}$ is the main component of $\mathrm{O}_{x}$, the budgets of $\mathrm{O}_{3}$ and $\mathrm{O}_{x}$ can be regarded as equivalent. $\mathrm{P}_{\mathrm{O}_{\mathbf{x}}}$ and $\mathrm{L}_{\mathrm{O}_{\mathbf{x}}}$ denote chemical production and destruction of $\mathrm{O}_{x}$ within the U.S. boundary layer.

${ }^{a}$ Estimated $\mathrm{O}_{x}$ production in the remote troposphere contributed by $\mathrm{NO}_{x}$ and PANs molecules exported from the U.S. boundary layer (see text).

${ }^{b}$ Ozone produced in the U.S. boundary layer from anthropogenic $\mathrm{NO}_{x}$ emitted within the region; its budget is obtained by subtracting the $\mathrm{O}_{3}$ budget in the zero- $\mathrm{NO}_{x}$ simulation from the $\mathrm{O}_{3}$ budget in the standard simulation.

estimate the exports of these species to the global atmosphere in different seasons. The model indicates a large seasonal variation of the $\mathrm{NO}_{x} / \mathrm{NO}_{y}$ ratio in the U.S. boundary layer, with values ranging from 0.2 in summer to 0.6 in winter; this result is consistent with observations at Harvard Forest, Massachusetts. The seasonal variation of the $\mathrm{NO}_{x} / \mathrm{NO}_{y}$ ratio is driven principally by the seasonal variation of the $\mathrm{NO}_{x}$ chemical lifetime. Formation of hydroxy organic nitrates from the oxidation of isoprene, followed by decomposition of these organic nitrates to $\mathrm{HNO}_{3}$, accounts for $30 \%$ of the $\mathrm{NO}_{x}$ sink in summer in our model. Recent laboratory measurements by P.B. Shepson (personal communication, 1997) indicate a $4.4 \%$ yield of hydroxy organic nitrates from oxidation of isoprene, lower than the $12 \%$ yield used here [Tuazon and Atkinson, 1990; Paulson and Seinfeld, 1992; Atkinson, 1994] and implying a smaller role of these nitrates in the summertime budget of $\mathrm{NO}_{y}$. The fraction of $\mathrm{NO}_{y}$ present as PANs in the U.S. boundary layer in the model is highest in spring ( $25 \%$ of total $\mathrm{NO}_{y}$ ), reflecting a combination of active photochemistry and low temperatures. Year-round observations of $\mathrm{NO}_{y}$ speciation (including PANs) at U.S. sites would be extremely valuable for testing our understanding of the seasonal variation in the $\mathrm{NO}_{y}$ budget.

We find in the model that $25-35 \%$ of $\mathrm{NO}_{x}$ emitted in the United States is exported as $\mathrm{NO}_{y}$ out of the continental boundary layer depending on season and that $60-80 \%$ of this export is in the form of $\mathrm{NO}_{x}$ or PANs and hence available to lead to $\mathrm{O}_{3}$ production in the remote troposphere. The fraction of $\mathrm{NO}_{y}$ present as $\mathrm{NO}_{x}$ or PANs in the exported air is larger than one would expect based on the speciation of concentrations in the U.S. boundary layer, because much of the export (especially in summer) takes place in wet convective updrafts where $\mathrm{HNO}_{3}$ is efficiently scavenged.

The response of $\mathrm{NO}_{y}$ export to change in $\mathrm{NO}_{x}$ emissions in the United States is found to be less than proportional in summer and more than proportional in winter, reflecting a seasonal transition in the photochemical regime of the continental boundary layer. Doubling $\mathrm{NO}_{x}$ emissions would increase the total export of $\mathrm{NO}_{x}$ and PANs by only $75 \%$ in summer but by $165 \%$ in winter.
The export of fossil fuel combustion $\mathrm{NO}_{x}$ and PANs from the U.S. boundary layer is estimated to be $1.4 \mathrm{Tg} \mathrm{N} \mathrm{yr}^{-1}$. This export represents an important source of $\mathrm{NO}_{x}$ to the northern hemisphere troposphere, comparable to the source from lightning. On the basis of model-derived $\mathrm{O}_{3}$ production efficiencies for the remote troposphere, we estimate that the $\mathrm{NO}_{x}$ and PANs exported from the United States eventually yield $8 \mathrm{Gmol} \mathrm{d}^{-1}$ of $\mathrm{O}_{3}$ on a global scale. In comparison, direct export of $\mathrm{O}_{3}$ pollution from the U.S. boundary layer in the model amounts to $4 \mathrm{Gmol}$ $\mathrm{d}^{-1}$. We conclude that the effect of U.S. pollution on global tropospheric $\mathrm{O}_{3}$ is determined principally, and in all seasons, by the export of $\mathrm{NO}_{x}$ and PANs from the continental boundary layer.

Acknowledgements. This work was supported by the National Oceanic and Atmospheric Administration (NA46GP0138), the National Science Foundation (NSF-ATM-96-12282), and the National Aeronautics and Space Administration (NASA-NAGW-2632 and NASA-NAG52688).

\section{References}

Atkinson, R., Gas-phase tropospheric chemistry of organic compounds: A review, J. Phys. Chem. Ref. Data, Monogr., 2, 1 216, 1994.

Atkinson, R., D.L. Baulch, R.A. Cox, R.F. Hampson, J.A. Kerr, and J. Troe, Evaluated kinetic and photochemical data for atmospheric chemistry, IV, IUPAC subcommittee on gas kinetic data evaluation for atmospheric chemistry, Atmos. Environ., Part A, 26, 1187-1230, 1992.

Balkanski, Y.J., D.J. Jacob, G.M. Gardner, W.C. Graustein, and K.K. Turekian, Transport and residence times of tropospheric aerosols inferred from a global three-dimensional simulation of ${ }^{210} \mathrm{~Pb}, J$. Geophys. Res. 98, 20,573-20,586, 1993.

Baughcum, S.L., T.G. Tritz, S.C. Henderson, and D.C. Pickett, Scheduled civil aircraft emission inventories for 1992: Database development and analysis, Rep. NASA CR-4700, NASA, Washington, D. C., 1996.

Benkovitz, C.M., M.T. Schultz, J. Pacyna, L. Tarrason, J. Dignon, E.C. Voldner, P.A. Spiro, J.A. Logan, and T.E. Graedel, 
Global gridded inventories for anthropogenic emissions of sulfur and nitrogen, J. Geophys. Res., 101, 29,239-29,253, 1996.

Chameides, W.L., F. Fehsenfeld, M.O. Rodgers, C. Cardetino, J. Martinez, D. Parrish, W. Lonneman, D.R. Lawson, R.A. Rasmussen, P. Zimmerman, J. Greenberg, P. Middleton, and $\mathrm{T}$. Wang, Ozone precursor relationships in the ambient atmosphere, J. Geophys., Res. 97, 6037-6055, 1992.

Chin, M., D.J. Jacob, G.M. Gardner, M.S. Foreman-Fowler, P.A. Spiro, and D.L. Savoie, A global three-dimensional model of tropospheric sulfate, J. Geophys. Res., 101, 18,667-18,690, 1996.

Crutzen, P.J., The role of $\mathrm{NO}$ and $\mathrm{NO}_{2}$ in the chemistry of the troposphere and stratosphere, Ann. Rev. Earth Planet. Sci., 7, 443-472, 1979.

DeMore, W.B., S.P. Sander, D.M. Golden, R.F. Hampson, M.J. Kurylo, C.J. Howard, A.R. Ravishankara, C.E. Kolb, and M.J. Molina, Chemical kinetics and photochemical data for use in stratospheric modeling, Evaluation No. 11, JPL Publ., 94-1, Jet Propul. Lab., Pasadena, Calif., 1994.

Dentener, F.J., and P.J. Crutzen, Reaction of $\mathrm{N}_{2} \mathrm{O}_{5}$ on tropospheric aerosols: impact on the global distribution of $\mathrm{NO}_{x}$ $\mathrm{O}_{3}$, and $\mathrm{OH}$, J. Geophys. Res., 98, 7149-7163, 1993.

Doddridge, B.G., R.R. Dickerson, R.G. Wardell, K.L. Civerolo, and L.J. Nunnermacker, Trace gas concentrations and meteorology in rural Virginia, 2, Reactive nitrogen compounds, J. Geophys. Res., 97, 20,631-20,646, 1992.

Environment Canada, Estimation of the effects of various municipal waste management strategies on greenhouse gas emissions, summary report, Ottawa, Ontario, Canada, 1995.

Fiore, A.M., D.J. Jacob, J.A. Logan, and J.H. Yin, Trends in ground level ozone over the contiguous United States from 1980 to 1995 , in press, 1997.

Galloway, J.N., D.M. Whelpdale, and G.T. Wolff, The flux of S and $\mathrm{N}$ eastward from North America, Atmos. Environ., 12, 2595-2607, 1984.

Goldstein, A.H., S.-M. Fan, M.L. Goulden, J.W. Munger, and S.C. Wofsy, Emissions of ethene, propene, and 1-butene by a midlatitude forest, J. Geophys. Res., 101, 9149-9157, 1996.

Gregory, G.L., and A.D. Scott, Compendium of NASA data base for the Global Tropospheric Experiment's Pacific Exploratory Mission-West A (PEM-West A), Rep. NASA TM-109177, NASA, Hampton, Va., 1995a.

Gregory, G.L., and A.D. Scott, Compendium of NASA data base for the global tropospheric experiment's Pacific Exploratory Mission-West B (PEM-West B), Rep. NASA TM-110193, NASA, Hampton, Va., 1995 b.

Grosjean, D., E. Grosjean, and E.L. Williams, Thermal decomposition of PAN, PPN, and vinyl-PAN, J. Air \& Waste Manage. Assoc., 44, 391-396, 1994.

Guenther, A., C.N. Hewitt, D. Erickson, R. Fall, C. Geron, T. Graedel, P. Harley, L. Klinger, M. Lerdau, W.A. Mckay, T. Pierce, B. Scholes, R. Steinbrecher, R. Tallamraju, J. Taylor, and P. Zimmermann, A global model of natural volatile organic compound emissions, J. Geophys. Res., 100, 88738892, 1995.

Hansen, J., G. Russell, D. Rind, P. Stone, A. Lacis, S. Lebedeff, R. Ruedy, and L. Travis, Efficient three-dimensional global models for climate studies: Models I and II, Mon. Weather Rev., 111, 609-662, 1983.

Holzworth, G.C., Mixing depths, wind speeds and air pollution potentials for selected locations in the United States, J. Appl. Meteorol., 6, 1039-1044, 1967.

Horowitz, L.W., J. Liang, G.M. Gardner, and D.J. Jacob, Export of reactive nitrogen from North America during summertime: Sensitivity to hydrocarbon chemistry, J. Geophys. Res., this issue.

Intergovernmental Panel on Climate Change (IPCC), Climate
Change 1994, edited by J.T. Houghton et al., p. 99, Cambridge Univ. Press, New York, 1995.

Jacob, D.J., and M.J. Prather, Radon-222 as a test of convective transport in a general circulation model, Tellus, Ser. B, 118134, 1990.

Jacob, D.J., et al., Simulation of summertime ozone over North America, J. Geophys. Res., 98, 14,797-14,816, 1993a.

Jacob, D.J., J.A. Logan, G.M. Gardner, R.M. Yevich, C.M. Spivakovsky, S.C. Wofsy, S. Sillman, and M.J. Prather, Factors regulating ozone over the United States and its export to the global atmosphere, J. Geophys. Res., 98, 14,817-14,826, $1993 \mathrm{~b}$.

Jacob, D.J., L.W. Horowitz, J.W. Munger, B.G. Heikes, R.R. Dickerson, R.S. Artz, and W.C. Keene, Seasonal transition from $\mathrm{NO}_{x}$ - to hydrocarbon-limited ozone production over the eastern United States in September, J. Geophys. Res., 100, 9315-9324, 1995.

Jacob, D.J., and 29 others, Evaluation and intercomparison of global atmospheric transport models using ${ }^{222} \mathrm{Rn}$ and other short-lived tracers, J. Geophys. Res., 102, 5953-5970, 1997.

Jacobson, M.Z., and R.P. Turco, SMVGEAR: a sparse-matrix, vectorized Gear code for atmospheric models, Atmos. Environ., Part A, 28, 273-284, 1994.

Kasibhatla, P.S., H. Levy II, and W.J. Moxim, Global NO , $\mathrm{HNO}_{3}, \mathrm{PAN}$, and $\mathrm{NO}_{3}$ distributions from fossil fuel combustion emissions: A model study, J. Geophys. Res., 98, 7165$7180,1993$.

Kirchner, F., and W.R. Stockwell, Effect of peroxy radical reactions on the predicted concentrations of ozone, nitrogenous compounds, and radicals, J. Geophys. Res., 101, 21,007$21,022,1996$.

Liang, J., and D.J. Jacob, Effect of aqueous-phase cloud chemistry on tropospheric ozone, J. Geophys. Res., 102, 5993-6001, 1997.

Liu, S.C., M. Trainer, F.C. Fehsenfeld, D.D. Parrish, E.J. Williams, D.W. Fahey, G. Hubler, and P.C. Murphy, Ozone production in the rural troposphere and the implications for regional and global ozone distributions, J. Geophys. Res., 92, 4191-4207, 1987.

Logan, J.A., Nitrogen oxides in the troposphere: Global and regional budgets, J. Geophys. Res., 88, 10,785-10,807, 1983.

Logan, J.A., Ozone in rural areas of the United States, J. Geophys. Res., 94, 8511-8532, 1989.

Logan, J.A., M.J. Prather, S.C. Wofsy, and M.B. McElroy, Tropospheric chemistry, A global perspective, J. Geophys. Res., $86,7210-7254,1981$.

Maricq, M. M., and J. J. Szente, Kinetics of the reaction between ethylperoxy radical and nitrogen oxide, J. Phys. Chem., 100, 12,374-12,379, 1996a.

Maricq, M. M., and J. J. Szente, Temperature-dependent study of the reaction between peroxyacetyl radicals and nitrogen oxide, J. Phys. Chem., 100, 12,380-12,385, 1996b.

McKeen, S.A., E.-Y. Hsie, and S.C. Liu, A study of the dependence of rural ozone on ozone precursors in the eastem United States, J. Geophys. Res., 96, 15,377-15,394, 1991.

Monson, R.K., P.C. Harley, M.E. Litrak, M. Wildermuth, A.B. Guenther, and P.R. Zimmermann, Environmental and development controls over the seasonal pattern of isoprene emission from aspen leaves, Oecologia, 99, 260-270, 1994.

Mozurkewich, M., and J. G. Calvert, Reaction probability of $\mathrm{N}_{2} \mathrm{O}_{5}$ on aqueous aerosols, J. Geophys. Res., 93, 15,889$15,896,1988$.

Olson, J., World ecosystems (WE1.4): Digital raster data on a 10 minute geographic $1080 \times 2160$ grid, in Global Ecosystems Database, Version 1.0: Disc A, edited by NOAA Nat. Geophys. Data Cent., Boulder, Colo., 1992.

Oltmans, S.J., and H. Levy II, Seasonal cycles of surface ozone over the western North Atlantic, Nature, 358, 392-394, 1992. 
Paulson, S.E., and J.H. Seinfeld, Development and evaluation of a photooxidation mechanism for isoprene, J. Geophys. Res., 97, 20,703-20,715, 1992.

Perros, P.E., Large-scale distribution of peroxyacetylnitrate from aircraft measurements during the TROPOZ II experiment, $J$. Geophys. Res., 99, 8269-8279, 1994.

Poulida, O., R.R. Dickerson, B.G. Doddridge, J.Z. Holland, R.G. Wardell, and J.G. Watkins, Trace gas concentrations and meteorology in rural Virginia, 1, Ozone and carbon monoxide, J. Geophys. Res., 96, 22,461-22,475, 1991.

Prather, M.J., M.B. McElroy, S.C. Wofsy, G. Russell, and D. Rind, Chemistry of the the global troposphere: Fluorocarbons as tracers of air motion, J. Geophys. Res., 92, 6579-6613, 1987.

Shepson, P.B., E. Mackay, and K. Muthuramu, Henry's Law constants and removal processes for several atmospheric $\beta$ hydroxy alkyl nitrates, Environ. Sci. Technol., 30, 3618-3623, 1996.

Sillman, S., J.A. Logan, and S.C. Wofsy, A regional scale model for ozone in the United States with subgrid representation of urban and power plant plumes, J. Geophys. Res., 95, 57315748,1990 a.

Sillman, S., J.A. Logan, and S.C. Wofsy, The sensitivity of ozone to nitrogen oxides and hydrocarbons in regional ozone episodes, J. Geophys. Res., 95, 1837-1851, $1990 \mathrm{~b}$.

Singh, H.B., Reactive nitrogen in the troposphere, Environ. Sci. Technol., 21, 320-327, 1987.

Singh, H.B., et al., Latitudinal distribution of reactive nitrogen in the free troposphere over the Pacific Ocean in late winter/early spring, J. Geophys. Res., in press, 1997.

Sirois, A., and J.W. Bottenheim, Use of backward trajectories to interpret the 5-year record of PAN and $\mathrm{O}_{3}$ ambient air concentrations at Kejimkujik National Park, Nova Scotia, J. Geophy. Res., 100, 2867-2881, 1995.

Spivakovsky, C.M., R. Yevich, J.A. Logan, S.C. Wofsy, M.B. McElroy, and M.J. Prather, Tropospheric $\mathrm{OH}$ in a threedimensional chemical tracer model: An assessment based on observations of $\mathrm{CH}_{3} \mathrm{CCl}_{3}, J$. Geophys. Res., 95, 18,441$18,472,1990$.
Thompson, A.M., K.E. Pickering, R.R. Dickerson, W.G. Ellis, D.J. Jacob, J.R. Scala, W.-K. Tao, D.P. McNamara, and J. Simpson, Convective transport over the central United States and its role in the regional $\mathrm{CO}$ and ozone budgets, J. Geophys. Res., 99, 18,703-18,711, 1994.

Trainer, M., E.J. Williams, D.D. Parrish, M.P. Buhr, E.J. Allwine, H.H. Westberg, F.C. Fehsenfeld, and S.C. Liu, Models and observations of the impact of natural hydrocarbons on rural ozone, Nature, 329, 705-707, 1987.

Tuazon, E.C., and R. Atkinson, A product study of the gas-phase reaction of isoprene with the $\mathrm{OH}$ radical in the presence of $\mathrm{NO}_{x}$, Int. J. Chem. Kinet., 22, 1221-1236, 1990.

U.S. Environmental Protection Agency (U.S. EPA), The 1985 NAPAP emission inventory (version 2): Development of the annual data and modeler's tapes, Rep. EPA-600/7-89-012a, Research Triangle Park, N. C., 1989.

U.S. EPA, National air pollutant emissions estimates, 1900-1994, Rep. EPA-454/R-95-011, Research Triangle Park, N. C., 1995.

U.S. National Acid Precipitation Assessment Program (NAPAP), 1990 integrated assessment report, Off. of the Dir., Washington, D. C., 1991.

Wesely, M.L., Parameterization of surface resistance to gaseous dry deposition in regional-scale numerical models, Atmos. Environ., 23, 1292-1304, 1989.

A. M. Fiore, G. M. Gardner, L.W. Horowitz, D. J. Jacob (corresponding author), J. A. Logan, J. W. Munger, and Y. Wang, Department of Earth and Planetary Sciences, Harvard University, Cambridge, MA 02138. (e-mail: djj@io.harvard.edu)

J. Liang, Department of Civil and Environmental Engineering, Stanford University, Stanford, CA 94041. (e-mail: jliang@standord.edu)

(Received March 26, 1997; revised October 21, 1997; accepted October 29, 1997.) 